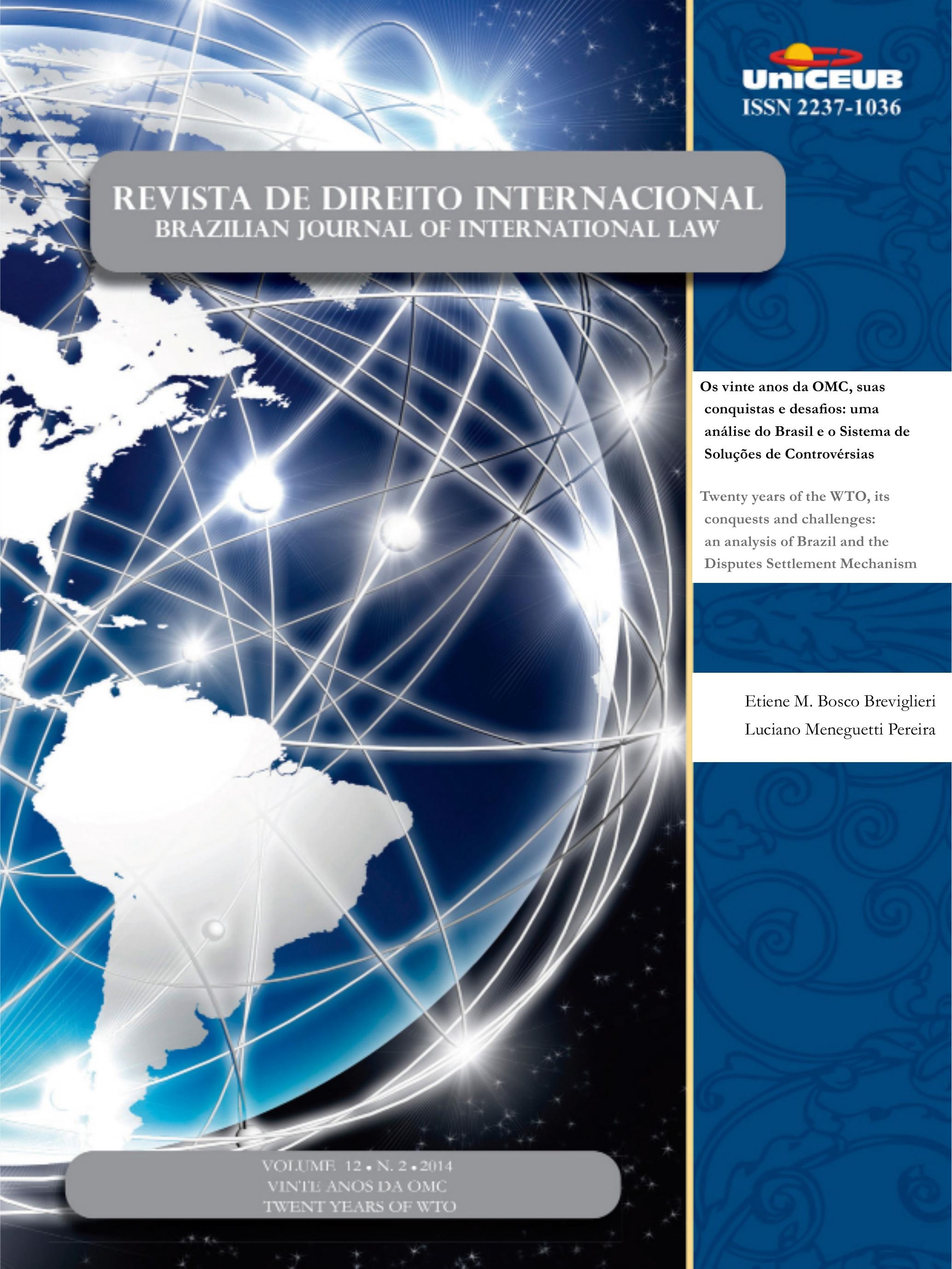


I. Crônicas

1. Crônicas da atualidade do Direito Internacional ......................................................16

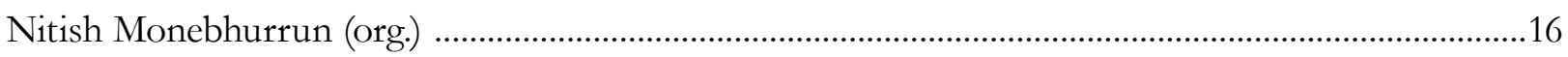

2.Decisões da Corte Internacional de Justiça e do Tribunal Internacional Sobre o Direito do Mar

Nitish Monebhurrun

José Eduardo Siqueira

3. Crônicas do direito internacional dos inVestimentos

Nitish Monebhurrun

\section{Os Vinte Anos dA OMC}

EXPORT CONTROLS AS INDUSTRIAL POLICY ON NATURAL RESOURCES: REGULATORY LIMITATIONS ON CHINA - RAW MATERIALS AND CHINA - RARE EARTHS CASES.

Gustavo Ferreira Ribeiro

O problema da espionagem econômica internacional: Seria a Organização Mundial do CoMÉRCIO O FORO ADEQUADO PARA SUA APRECIAÇÃO?

Humberto A.Vasconcelos Lima

Naiana Magrini Rodrigues Cunha

International Standards for Intellectual Property Rights Protection: a reflection on CLIMATE-FRIENDLY TECHNOLOGY TRANSFER.

Guihong Zhang

Jiani Jiang

Can Wang

Os vinte anos da OMC, suas conquistas e desafios: uma análise do Brasil e o Sistema de SoLUÇõES DE CONTROvÉRsias

Etiene M. Bosco Breviglieri

Luciano Meneguetti Pereira

A relação entre os tratados multilaterais ambientais e os acordos da OMC: é possível CONCILIAR O CONFLITO?

Fabio Costa Morosini,

Luisa Zuardi Niencheski 
Um desafio na OrganizaÇão Mundial do Comércio: viabilidade de um aCordo plurilateral

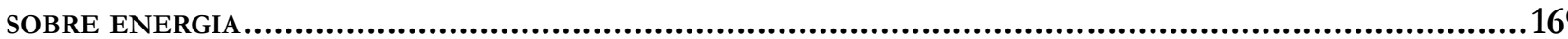

Matheus Linck Bassani

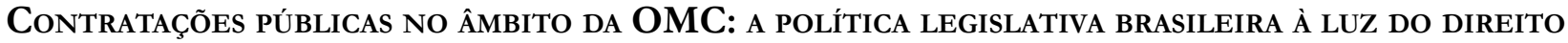
AO DESENVOLVIMENTO

André Jansen do Nascimento

Governança global e a Organização Mundial do Comércio: desafios impostos pelo novo MANDATO DE DESENVOLVIMENTO

Letícia de Souza Daibert

Ana Luísa Soares Peres

Vinte Anos de Crise para a África? Poder, Assimetrias e a Abordagem Liberal da OMC.....239 Igor Abdalla Medina de Souza

Os MECANISMOS DE INDUÇÃo AO CUMPRIMENTO NO ÂMBITO DA OMC

Fernando Lopes Ferraz Elias

A promoção de accountability na Organização Mundial do Comércio: uma análise horiZONTAL E VERTICAL.

Celso Henrique Cadete de Figueiredo

LA OMC Y EL PROCESO DE GLOBALIZACION DE LA REGULACIÓN ALIMENTARIA

Maria Eugenia Marichal

O ACORDO GATS E SUA APLICAÇÃO AOS SERVIÇOS DO COMÉRCIO ELETRÔNICO

Gleisse Ribeiro Alves

A OMC E O REGIONALISMO do SÉCUlO XXI: ESTRATÉGIA DE IMPOSIÇÃo DE MODELOS NORMATIVOS? .. 337

Camilla Capucio

A ORganização MUNDIAL do COMÉRCIO E A CHINA: DIREITO DE PROPRIEDADE E PROPRIEDADE INTELECTUAL NO PAÍS

Dos CONTEnCiOsos NA OMC COM ENFOQUe EM RESTRIÇÕES Às EXPORTAÇÕES DA CHINA 363 Marco Antônio Alcântara Nascimento 
O Redimensionamento da OMC no trato dos Acordos Comerciais Regionais.

Alice Rocha da Silva

\section{Outros Temas}

Derechos Humanos en la REALIDAd ACtual: LA GLOBALIZACión Y El MUlticulturalismo

David Falcão

IMUNIDADE DE JURISDIÇÃo do ESTADO E REPARAÇÃo CIVIL PELA PRÁTICA DE TORTURA: O CASO ZaHRA

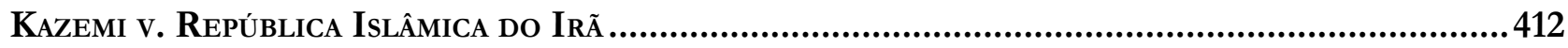

Patrícia Maria Lara Abreu

Rodrigo Otávio Bastos Silva Raposo

INTERREgIONAL ORgANIZATIONS (IROS) IN EUROPE: NEW SUBJECTS OF CONTEMPORARY INTERNATIONAL LAW?

Davorin Lapas

A Conexão entre os direitos humanos e a CORRupÇão.

Gabriela Alves Mendes Vieira

Marcelo Dias Varella

GRUPO DE SOCIEDADES: INSTRUMENTO JURÍDICO DE ORGANIZAÇÃo DA EMPRESA PLURISSOCIETÁRIA.....495

Daniel Amin Ferraz 


\title{
Os vinte anos da OMC, suas conquistas e desafios: uma análise do Brasil e o Sistema de Soluções de Controvérsias*
}

\author{
Twenty years of the WTO, its conquests and \\ challenges: an analysis of Brazil and the Disputes \\ Settlement Mechanism
}

Etiene M. Bosco Breviglieri** Luciano Meneguetti Pereira***

* Recebido em 18.10.2014

Aceito em 12.11.2014

** Pós-Doutoranda pela Università degli Studi di Messina (Itália); Doutora em Direito Civil Comparado pela PUC/SP; Mestre em Direito Internacional pela UNESP/Franca; Mestre em Letras pela UNESP/SJRP. Professora na Universidade Estadual de Minas Gerais (UEMG) - Campus de Frutal, na Universidade Paulista (UNIP) e no Instituto Municipal de Ensino Superior de Catanduva (IMES).

***Mestre em Direito Constitucional pelo Instituto Toledo de Ensino (ITE); Especialista em Direito Público com ênfase em Direito Constitucional pela Universidade Potiguar (UNP); Graduado em Direito pelo Centro Universitário Toledo (UNITOLEDO); Professor de Direito Internacional e Direitos Humanos no Centro Universitário Toledo (UNITOLEDO) e na Associação de Ensino do Mato Grosso do Sul (AEMS); Advogado, lmeneguetti@gmail.com.

\section{Resumo}

O objetivo desse artigo é analisar os aspectos mais importantes da atuação da OMC em seus vinte anos de existência. Diante da importância cada vez mais crescente da temática do comércio internacional nos arranjos globais das últimas décadas, diversos e importantes questionamentos têm sido levantados acerca da capacidade operacional da OMC, seus pressupostos teóricos e sua competência para desempenhar o papel para o qual foi concebida, isto é, ser a arquiteta e regente do comércio internacional no mundo. $\mathrm{O}$ artigo primeiramente apresenta a $\mathrm{OMC}$, seus objetivos, funções e estrutura. Em seguida são verificadas as principais conquistas obtidas pela organização ao longo de sua existência, para então serem abordados os principais problemas por ela enfrentados, assim como os desafios que deverão ser superados para que possa manter a sua relevância no contexto de um mundo globalizado e regionalizado. Ao final são abordados os principais aspectos do órgão de solução de controvérsias da organização, bem como o relacionamento do Brasil com esse órgão e as principais disputas ocorridas.

Palavras-chave: Comércio Internacional. Globalização. OMC. Sistema de Solução de Controvérsias. Brasil.

\begin{abstract}
The aim of this paper is to analyze the most important aspects of the performance of the WTO in its twenty years of existence. Given the everincreasing importance of the theme of international trade in global arrangements in the last few decades, several important questions have been raised about the operational capacity of WTO, its theoretical assumptions and its competence to perform the role for which it was designed, namely to be the architect and conductor of international trade in the world. The article first presents the WTO, its objectives, functions and structure. Next, are analyzed the main achievements obtained by the organization throughout its existence, to then be addressed the main problems faced by the organization as well as the challenges that must be overcome in order to WTO maintain its relevance in the context of a globalized and regionalized world. Finally, the main aspects of the dispute settlement body of the organization are addressed as well as the relations between Brazil and WTO and the major disputes occurred.
\end{abstract}

Keywords: International Trade. Globalization. WTO. Dispute Settlement System. Brazil. 


\section{Aspectos introdutórios}

Há vinte anos nascia a Organização Mundial do Comércio (OMC), exatamente em 15 de abril de 1994, com início de suas operações em $1^{\circ}$ de janeiro de 1995. Uma organização internacional concebida em meio a grandes expectativas para ser a arquiteta do comércio mundial. Nascia para ser uma instituição guia da globalização, com a missão de eliminar barreiras de negociação e acesso ao comércio internacional, limitar o protecionismo dos mercados internos, facilitando notadamente o ingresso dos países em desenvolvimento, dentre tantos outros obstáculos.

Passados vinte anos, o transcurso do tempo se encarregou de revelar que os obstáculos a serem vencidos pela organização seriam muito mais difíceis do que se esperava. É certo que muitas coisas foram conquistadas, mas as disputas políticas, a estrutura pouco ágil para o oferecimento de respostas rápidas, exigidas pela dinâmica evolutiva do comércio internacional no contexto de um mundo globalizado, o surgimento e o fortalecimento de blocos econômicos regionais e, notadamente algumas instituições da organização, como a regra do consenso, deram ensejo a uma lista de "fracassos" que a OMC não conseguiu evitar, o que acabou por colocar em xeque a sua credibilidade, sua capacidade para cumprir com os objetivos e funções estabelecidos em seu documento constitutivo, enfim, a sua relevância para o comércio internacional em pleno século XXI, não sendo desarrazoada a afirmação de que a $\mathrm{OMC}$ vive hoje uma crise existencial.

Nesses vinte anos que se passaram desde a sua criação, a OMC, oferecendo pioneiramente uma base jurídica sólida para o sistema de comércio multilateral, estabeleceu uma longa trajetória de inserção de diferentes Estados no mercado internacional, permitindo que alguns países membros tivessem mais segurança jurídica, estabilidade e previsibilidade nas intensas relações comerciais internacionais que se multiplicaram nas últimas duas décadas, o que certamente constitui uma das importantes conquistas da organização.

Diante da necessidade do estabelecimento de um processo de integração de normas capaz de permitir um fluxo contínuo e, na medida do possível, igualitário, entre os diferentes mercados presentes nas diversas regiões do planeta, uma tarefa árdua que apresentou e apresenta muitas dificuldades em razão dos inúmeros conflitos inerentes aos interesses contrastantes dos Estados-membros, criou-se também no âmbito da
OMC um órgão solucionador de controvérsias (OSC), também conhecido como Sistema de Solução de Controvérsias (SSC), o que também constituiu um grande avanço à época e contribuiu inicialmente de forma significativa para o alcance dos objetivos da organização.

Porém, no início de século XXI, no contexto de um mundo globalizado, em que a marca é o rápido e intenso relacionamento (global e regional) entre os países, notadamente na área da economia, a dinâmica das relações comerciais internacionais têm imposto à OMC a adoção de uma nova postura, principalmente no que tange ao oferecimento de respostas rápidas da organização para as questões comerciais entre os seus países-membros, v.g., aquelas situações de conflitos que se apresentam, decorrentes das relações comerciais entre os países; a necessidade do estabelecimento de acordos multilaterais globais que sejam efetivos etc. Surge para a OMC, até como uma condição sine qua non para a sua sobrevivência, a necessidade de se adaptar a uma nova tônica que vem sendo impressa no comércio internacional pela globalização, sobretudo, no tocante à necessidade de uma reestruturação organizacional e adaptação de suas regras aos novos desafios surgidos.

Nesse contexto, o presente texto em primeiro momento analisará de forma sucinta as principais conquistas obtidas pela $\mathrm{OMC}$, bem como os principais problemas e desafios enfrentados desde a sua criação e que persistem atualmente. Em seguida serão tecidas considerações sobre o órgão solucionador de controvérsias da organização, analisando-se seus principais aspectos e sua atividade, para então verificar como tem sido o relacionamento do Brasil com a $\mathrm{OMC}$, notadamente no aspecto pertinente à solução de controvérsias ocorridas no âmbito da organização.

\section{A Organização Mundial do Comércio: conquistas e desafios}

Pode-se afirmar que, ao longo das últimas décadas, as necessidades comerciais de cada país aumentaram sobremaneira, fazendo intensificar-se o relacionamento comercial entre os diversos países do globo, fator que foi facilitado pelo avanço científico e tecnológico, notadamente nos meios de comunicação e transporte. Apenas para exemplificar um fenômeno de influência e modificação das relações comerciais globais, pode-se citar o crescimento vertiginoso da internet, que trouxe consigo uma nova espécie de economia: a economia digital, 
acarretando a formação de um mercado eletrônico (ou virtual) e o aparecimento das "ciberempresas", de matriz tecnológica. Concomitantemente, um fenômeno que se tem assistido é migração de empresas tradicionais para o mercado eletrônico, inclusive, com o abandono do ambiente físico por parte de muitas delas, para operarem apenas no ambiente virtual.

Esses e muitos outros fatores sem dúvida constituíram molas propulsoras para um intenso relacionamento comercial dos países em escala global e também facilitaram o relacionamento entre países por meio da criação de diversos blocos econômicos ou pelo aprimoramento daqueles já existentes mesmo antes do advento da era tecnológica, conforme se vê na atualidade, v.g., União Europeia (UE), Mercado Comum do Sul (MERCOSUL), Associação LatinoAmericana de Integração (ALADI), Tratado NorteAmericano de Livre Comércio (NAFTA), Associação de Nações do Sudeste Asiático (ASEAN) etc. É possível afirmar, portanto, que foi e é a necessidade de regras de intercâmbio, convivência e sobrevivência (no mundo físico e no mundo virtual) para esse mercado internacional, indispensáveis no contexto atual de globalização, que dá origem a organizações como a OMC e que também exigem a sua constante atualização para que possa acompanhar a dinâmica das relações comerciais internacionais.

\subsection{Entendendo a OMC}

A $\mathrm{OMC}^{1}$, com sede em Genebra, na Suíça, é uma organização com personalidade jurídica de Direito

1 A OMC foi criada a partir dos acordos e compromissos firmados em Marraqueche, como resultado da Rodada Uruguai (1990), objetivando-se, dentre outras coisas, interpretar e modificar substancialmente artigos específicos do tratado anterior regente da matéria, denominado GATT, que é Acordo Geral sobre Tarifas e Comércio (General Agreement on Tariffs and Trade), criado em 1947, visando harmonizar as políticas aduaneiras dos Estados signatários e que tornou-se a base da criação da Organização Mundial de Comércio. O GATT, ainda existente e parcialmente em vigor, é composto por um conjunto de normas e concessões tarifárias, criado com a função precípua de impulsionar a liberalização comercial e combater práticas protecionistas nas relações comerciais internacionais. No Brasil, a Ata Final da Rodada Uruguai, subscrita em Marraqueche, foi aprovada pelo Congresso Nacional por meio do Decreto Legislativo n. 30, de 15 de dezembro de 1994, e promulgada por meio do Decreto n. 1.355/94, de 30 de dezembro, assinado pelo então Presidente Itamar Franco, que estabeleceu sua vigência a partir de $1^{\circ}$ de janeiro de 1995. Disponível em: <http://www.planalto.gov.br/ccivil_03/decreto/1990-1994/ anexo/and1355-94.pdf>. Acesso em: 14 out. 2014.
Internacional, de natureza intergovernamental, conforme dispõe o art. $8^{\circ}$, 1 e 2, de seu Acordo Constitutivo. ${ }^{2}$ Aliás, nesse sentido reside um dos maiores diferenciais entre o sistema de regulação do comércio internacional anterior e a atual organização, pois enquanto o GATT foi apenas um acordo entre países, a OMC é uma organização dotada de personalidade internacional. Conforme explica Paulo Estivallet de Mesquita,

Os resultados da Rodada Uruguai foram amplos, profundos e, em boa medida, revolucionários. O sistema do GATT baseava-se em um acordo de status inferior a um tratado internacional (em virtude do Protocolo de Aplicação Provisória), limitado ao comércio de bens — e mesmo nesse caso, com setores excluídos —, com um mecanismo de solução de controvérsias que dependia do consentimento da parte reclamada e com um arranjo institucional precário. $\mathrm{O}$ acordo de Marraqueche, que estabeleceu a OMC, transformou o sistema de comércio multilateral de maneira radical. ${ }^{3}$

Ernest H. Preeg, discorrendo sobre a amplitude e importância da Rodada do Uruguai, que culminou com a criação da $\mathrm{OMC}$, afirma que

A Rodada Uruguai, iniciada em Punta del Este, Uruguai, em setembro de 1986, e concluída em Marrakesh, Marrocos, em março 1994, foi a mais importante e bem-sucedida das oito rodadas de negociações multilaterais do Acordo Geral sobre Tarifas e Comércio (GATT). Tarifas para o comércio não agrícola foram reduzidas de forma substancial e um quadro de liberalização do comércio para a agricultura foi adotado. Comércio de serviços e direitos de propriedade intelectual foram incorporados no sistema de negociações. Procedimentos de solução de controvérsias foram sobremaneira fortalecidos e quotas bilaterais de importação de têxteis foram eliminadas. Outros notáveis acordos foram alcançados, como medidas relacionadas ao comércio de

2 Os textos dos acordos da OMC podem ser consultados no sítio do Ministério das Relações Exteriores - Itamaraty: Disponível em: $\quad<$ http://www.itamaraty.gov.br/o-ministerio/conheca-oministerio/tecnologicos/cgc/solucao-de-controversias/maisinformacoes/texto-dos-acordos-da-omc-portugues $>$. Acesso em: 14 out. 2014.

3 MESQUITA, Paulo Estivallet de Mesquita. A Organização Mundial do Comércio. Brasília: FUNAG, 2013, e-book. 
investimentos, subsídios à exportação, antidumping, compras governamentais, salvaguardas, medidas sanitárias e fitossanitárias e barreiras técnicas ao comércio. E, embora não faça parte do mandato de negociação original, a Organização Mundial do Comércio (OMC) foi criada durante a fase final das negociações, que incorporou todos os elementos do Acordo da Rodada do Uruguai e as disposições de longa data do GATT. ${ }^{4}$

A OMC, portanto, constitui um organismo internacional com personalidade jurídica própria, distinta da de seus membros. Bernard M. Hoekmanis e Petros C. Mavroidis explicam que,

em poucas palavras, a OMC é tanto um mecanismo de troca (comércio) de compromissos de políticas comerciais como um acordo sobre um código de condutas.

Certamente a OMC constitui um organismo internacional que exerce papel fundamental na regulamentação do comércio internacional, atuando notadamente na solução de conflitos que, porventura, ocorrem entre os Estados-membros, que desde junho de 2014 totalizam 160 países. ${ }^{6}$

4 PREEG, Ernest. H. The Uruguay Round Negotiations and the Creation of the WTO. In: NARLIKAR, Amrita; DAUNTON, Martin; STERN, Robert M. The Oxford Handbook on the World Trade Organization. New York: Oxford University Press, 2012, e-book. "The Uruguay Round, launched at Punta del Este, Uruguay, in September 1986, and concluded at Marrakesh, Morocco, in March 1994, was the most important and successful of the eight General Agreement on Tariffs and Trade (GATT) rounds of multilateral negotiations. Tariffs on non-agricultural trade were reduced substantially and a trade liberalization framework for agriculture was adopted. Trade in services and intellectual property rights were incorporated within the trading system. Dispute procedures were strengthened greatly and bilateral import quotas for textiles were phased out. Other noteworthy agreements were reached for trade-related investment measures, export subsidies, anti-dumping, government procurement, safeguards, sanitary and phytosanitary measures, and technical barriers to trade. And, although not part of the original negotiating mandate, the World Trade Organization (WTO) was created during the final phase of the negotiations, which incorporated all elements of the Uruguay Round Agreement and the long-standing provisions of the GATT",

5 HOEKMAN, Bernard M.; MAVROIDIS, Petros C. The World Trade Organization: law, economics, and politics. Abingdon: Routledge, 2007, p. 15. "in a nutshell, the WTO is both a mechanism for exchanging (trading) trade policy commitments, and agreeing on a code of conduct"

6 A tabela de membros da OMC e seus detalhes pode ser consultada no sítio da própria WTO. Disponível em: <http://www. wto.org/english/thewto_e/whatis_e/tif_e/org6_e.htm>. Acesso em: 14 out. 2014
Em relação aos seus objetivos, conforme disposto no art. $2^{\circ}$ de seu tratado constitutivo, a "OMC constituirá o quadro Institucional comum para a condução das relações comerciais entre seus Membros". Conforme explica Pedro Talavera Déniz, a OMC nasceu com os seguintes objetivos: a) criar uma organização supranacional, capaz de administrar e regulamentar o comércio internacional; b) propiciar um maior e melhor acesso aos mercados, de modo a evitar as restrições protecionistas às importações; c) combater o comércio desleal nas exportações, evitando o crescimento artificial e desmedido de produtos não competitivos ou de mercadorias falsificadas; d) permitir aos países intervenientes o prévio conhecimento das normas regulamentares que afetem suas atividades; e) abarcar e disciplinar todas as transações internacionais, alcançando uma vasta gama de produtos, inclusive com regras específicas em relação à prestação de serviços; f) estabelecer um procedimento na solução de conflitos capaz de garantir aos seus membros o reconhecimento dos direitos negociados e o cumprimento das obrigações assumidas; e g) ser, em suma, um organismo de vocação universal. ' Seus objetivos, em síntese, resumem-se,

na intenção de desenvolver um sistema comercial multilateral integrado, mais viável e durável, baseado no GATT, nos resultados das rodadas de liberalização comercial anteriores e nos resultados da Rodada Uruguai. ${ }^{8}$

No tocante ao seu aspecto funcional, em síntese suas funções abrangem a administração dos acordos e dos mecanismos de solução de controvérsias e de revisão de políticas comerciais. Além disso, a Organização serve como fórum de negociações comerciais multilaterais?

conforme disposto no art. $3^{\circ}$ de seu documento constitutivo. $^{10}$

7 DÉNIZ, Pedro Talavera. La Regulación Del Comercio Internacional: del GATT a la OMC. Barcelona: Universitat de Barcelona, 1995, p. $45-46$.

8 MESQUITA, Paulo Estivallet de Mesquita. A Organização Mundial do Comércio. Brasília: FUNAG, 2013, e-book.

9 MESQUITA, Paulo Estivallet de Mesquita. A Organização Mundial do Comércio. Brasília: FUNAG, 2013, e-book.

10 “Artigo III - Funções da OMC. 1. A OMC facilitará a aplicação administração e funcionamento do presente Acordo e dos Acordos comerciais multilaterais e promoverá a consecução de seus objetivos e constituirá também o quadro jurídico para a aplicação, administração e funcionamento dos Acordos comerciais Plurilaterais. 2. A OMC será o foro para as negociações entre seus Membros acerca de suas relações comerciais multilaterais em assuntos tratados no quadro 
A estrutura institucional da OMC está prevista no seu art. $4^{\circ}$, sendo um tanto complexa. Funciona basicamente em quatro níveis organizacionais, em que há uma grande quantidade de comitês e grupos de trabalhos. ${ }^{11}$ Sua estrutura é composta precipuamente por seus membros, que são países ou "territórios aduaneiros". ${ }^{12}$ Mesquita explica que

A estrutura da OMC tem, no ápice, a Conferência Ministerial, que se reúne a cada dois anos. No dia a dia, o órgão decisório máximo é o Conselho Geral, integrado pelos Representantes Permanentes de todos os Membros. O Conselho Geral também se reúne como Órgão de Solução de Controvérsias e como Órgão de Revisão de Políticas Comerciais. Abaixo do Conselho Geral estão os Conselhos de Comércio de Bens, Comércio de Serviços e TRIPS. Abaixo destes, por sua vez, há cerca de quatro dezenas de Comitês, Subcomitês e Grupos de Trabalho, que administram acordos específicos ou mesmo aspectos distintos de um mesmo acordo. Essa estrutura é servida pelo Secretariado, dirigido por um Diretor-Geral. ${ }^{13}$

Conforme pode-se verificar, as Conferências Ministeriais (art. $\left.4^{\circ}, 1\right)$, conhecidas também como

dos acordos incluídos nos Anexos ao presente Acordo. A OMC poderá também servir de foro para ulteriores negociações entre seus Membros acerca de suas relações comercias multilaterais e de quadro Jurídico para a aplicação dos resultados dessas negociações secundo decida a Conferência Ministerial. 3. A OMC administrará o entendimento relativo às normas e procedimentos que regem a solução de controvérsias (denominado a seguir 'Entendimento sobre Solução de controvérsias' ou 'ESC') que figura no Anexo 2 do presente Acordo. 4. A OMC administrará o mecanismo de Exame das Políticas comerciais (denominado a seguir 'TPRM') estabelecido no anexo 3 do presente Acordo. 5. Com o objetivo de alcançar uma maior coerência na formulação das políticas econômicas em escala mundial, a OMC cooperará no que couber com o Fundo Monetário Internacional e com o Banco Internacional de Reconstrução e Desenvolvimento e com os órgãos a eles afiliados".

11 O organograma estrutural da OMC pode ser consultado no próprio sítio da organização na internet. Disponível em:

<http://www.wto.org/english/thewto_e/whatis_e/tif_e/utw_ chap7_e.pdf>. Acesso em: 14 out. 2014.

12 São territórios com capacidade jurídica para implementar acordos de comércio, mesmo não constituindo técnica $\mathrm{e}$ juridicamente Estados nacionais, v.g., Hong Kong, Taiwan e União Europeia.

13 MESQUITA, Paulo Estivallet de Mesquita. A Organização Mundial do Comércio. Brasília: FUNAG, 2013, e-book. "rodadas", configuram o primeiro e mais alto nível do processo de tomada de decisões da OMC, sendo que nelas são definidos os temas que serão tratados pelos Estados-membros em cada rodada de negociação, que deve ocorrer num prazo de até dois anos.

O segundo nível organizacional está representado por três organismos: o Conselho Geral, o Órgão de Solução de Controvérsias (OSC) e o Órgão de Revisão de Politica Comercial (ORPC).

O órgão mais expressivo é o Conselho Geral (art. $4^{\circ}$, 2), órgão permanente constituído por embaixadores ou chefes de delegações de todos os Estados-membros, cuja função precípua é zelar pelos acordos multilaterais, administrar as atividades diárias da OMC, bem como executar as decisões tomadas nas Conferências Ministeriais.

Os outros dois órgãos que se encontram no mesmo nível auxiliam o Conselho Geral no desempenho de suas tarefas. Um deles é o Órgão de Solução de Controvérsias OSC (art. $4^{\circ}, 3$ ), composto por todos os membros da organização, sendo a instituição máxima do sistema de solução de litígios no âmbito da organização e que será abordado mais adiante. O outro é o Órgão de Revisão de Politica Comercial - ORPC (art. $\left.4^{\circ}, 4\right)$, criado com o objetivo de estabelecer um cronograma anual de entrega de relatórios periódicos dos membros da OMC, com base nos acordos multilaterais de comércio, tem como incumbência verificar a consistência das políticas econômicas adotadas pelos países.

No terceiro nível dentro da estrutura orgânica da OMC, estão presentes três acordos: o GATT, O GATS e o TRIPS. O primeiro, Acordo Geral sobre Tarifas e Comércio (General Agreement on Tariffs and Trade - (GATT), que deu origem à $\mathrm{OMC}$, como já se deu notícia, atualmente está inserido no âmbito da organização para regular as tarifas e o comércio.

O segundo, Acordo Geral de Comércio de Serviços (General Agreement on Trade in Service - GATS), tem como finalidade estabelecer um quadro referencial multilateral de princípios e regras para o comércio internacional.

Por fim, o terceiro, denominado Acordo sobre Aspectos do Direito da Propriedade Intelectual Relacionados ao Comércio (Agreement on Trade-Related Aspects of Intellectual Property Rights - TRIPS), tem como escopo criar um ambiente para negociações multilaterais com base em princípios, regras e disciplina relacionados com os direitos de propriedade intelectual em disputa pelos países. 
O quarto e último nível organizacional da OMC é constituído por uma grande quantidade de comitês e grupos de trabalhos que tratam de temas diversos (v.g., o Comitê de Comércio e Desenvolvimento, o Comitê de Restrições por Balanço de Pagamentos, o Comitê de Assuntos Orçamentários, Financeiros e Administrativos etc.), como acesso a mercados, subsídios, e comitês permanentes que lidam com a administração, o orçamento e as finanças; comércio e meio ambiente; acordos regionais etc.

De um modo geral, essa estrutura organizacional tem sido objeto de críticas em razão de sua complexidade e inadequação para tratar de modo eficiente as questões do comércio internacional multilateral hodiernas que têm-se apresentado como desafios à $\mathrm{OMC}$, conforme tratado mais adiante.

\subsection{As conquistas da OMC}

Era comum o entendimento dos Estados-membros, quando da criação da OMC, de que as relações na esfera da atividade comercial e econômica deveriam objetivar a elevação dos níveis de vida, o pleno emprego, o aumento da produção e do comércio de bens e de serviços, permitindo simultaneamente a utilização ótima dos recursos mundiais de conformidade com o desenvolvimento sustentável, buscando-se proteger e preservar o meio ambiente bem como desenvolver os meios para fazê-lo, de maneira compatível com as respectivas necessidades e interesses de cada Estado, segundo os diferentes níveis de desenvolvimento econômico.

Os países também reconheciam naquele momento a necessidade de envidarem-se esforços positivos para que países em desenvolvimento, especialmente os de menor desenvolvimento relativo, pudessem obter uma parte do incremento do comércio internacional que correspondesse às necessidades de seu desenvolvimento econômico. Afirmavam naquele instante a intenção em contribuir para a consecução desses objetivos mediante a celebração de acordos destinados a obter, na base da reciprocidade e de vantagens mútuas, a redução substancial das tarifas aduaneiras e dos demais obstáculos ao comércio, assim como a eliminação do tratamento discriminatório nas relações comerciais internacionais. É, nesse contexto, nesse misto de otimismo e boas intenções e expectativas que nasceu a primeira organização regente do comércio internacional multilateral em âmbito mundial.

Conforme já se afirmou, a OMC foi pioneira no plano internacional em oferecer uma base jurídica sólida (Acordo de Estabelecimento da Organização Mundial de Comércio) para o sistema de comércio internacional multilateral, o que se deu por meio dos acordos firmados em Marraqueche, como resultados da Rodada Uruguai de Negociações Comerciais Multilaterais. Sem dúvida esse fato consiste numa grande conquista para os Estados-membros originários e para todos aqueles que puderam ingressar ulteriormente no mercado internacional, graças ao novo sistema instituído no âmbito da OMC. Afinal, a organização ainda é hoje o único fórum em que são definidas as regras para o comércio mundial, o que confere aos Estadosmembros maior segurança jurídica em suas relações, assim como maior estabilidade e previsibilidade nas relações comerciais internacionais desencadeadas.

Também como já se apontou, a OMC, ao longo dos vinte anos de sua existência, estabeleceu uma longa trajetória de inserção de diferentes Estados no mercado internacional. Certamente, a adesão de parceiros de peso como a China, a Arábia Saudita e a Rússia consistiram em importante conquista da organização.

O sistema de solução de controvérsias (OSC) da OMC possivelmente constitui o principal sucesso da organização. Com a sua instituição, passou a ser possível a resolução de disputas comerciais dentro de um procedimento de disputa regulamentado. Por essa razão, até mesmo os países em desenvolvimento conseguem ter êxito em disputas contra grandes potências industriais, a exemplo da União Europeia que já teve repetidas vezes que ajustar suas regras às determinações da OMC. Em relação ao mecanismo de administração de conflitos instituído no âmbito da organização, Celso Lafer pondera que

O mercado e a concorrência podem ser vistos como uma grociana luta de todos em prol de todos. Essa é a tese do doux commerce. Simmel observou que o mercado e a concorrência são, no entanto, simultaneamente uma hobbesiana guerra de todos contra todos [...]. Para evitar a confrontação bélica de uma concorrência desenfreada 'baseada no poder', a administração do conflito e da cooperação no mercado requer um enquadramento jurídico. A OMC prevê esse enquadramento através de um ordenamento 
jurídico, o single undertaking, concebido como um jogo de normas de fair play compartilhadas por todos os membros [...]. O sistema de solução de controvérsias da OMC representa não só codificação, mas um desenvolvimento progressivo do direito e da prática do GATT. ${ }^{14}$

Ainda que atualmente se deva admitir a necessidade de aperfeiçoamento do mecanismo de solução de controvérsias da $\mathrm{OMC}$ em diversos aspectos, não há dúvidas de que ele constituiu um avanço institucional de singular importância no campo das relações comerciais internacionais. Roberto Azevêdo, ao ressaltar a importância do OSC esclarece que

A adoção do chamado "consenso reverso",
segundo o qual decisões importantes como
o estabelecimento de painéis ou a adoção de
relatórios são automaticamente tomadas caso não
se verifique a oposição do conjunto dos membros
da OMC, trouxe maior previsibilidade ao sistema.
A criação de uma instância recursal, o Órgão de
Apelação, por sua vez, atribuiu maior juridicidade
à complexa tarefa de dirimir litígios comerciais
entre Estados soberanos. Por fim, a admissão do
direito de suspender concessões e obrigações na
hipótese de descumprimento de suas decisões
— ou seja, de "retaliar" — conferiu ao sistema
grau de atratividade e confiança que não encontra
paralelo em outras cortes internacionais. ${ }^{15}$

Para o Brasil, o mecanismo de solução de controvérsias da OMC é considerado uma das principais realizações da Rodada Uruguai do GATT, pois, além de cumprir com a sua função precípua de resolver os conflitos comerciais ocorrentes entre os membros da OMC, o mecanismo tem-se revelado um instrumento fundamental no tocante à interpretação dos compromissos assumidos no âmbito dos acordos que conformam o sistema multilateral de comércio, bem como na criação de jurisprudência que, na prática, acaba por preencher lacunas e equacionar ambiguidades que não raras as vezes se fazem presentes nas disciplinas multilaterais do comércio. ${ }^{16}$

14 LAFER, Celso. AOMC e a regulamentação do comércio internacional: uma visão brasileira. Porto Alegre: Livraria do Advogado, 1998, p. 9.

15 AZEVÊDO, Roberto Carvalho de. O Brasil e o Mecanismo de Solução de Controvérsias da OMC. In: LIMA, Maria Lúcia Labate Mantovanini Padua; ROSENBERG, Barbara (Coords.). O Brasil e o contencioso na OMC. Tomo I. São Paulo: Saraiva, 2009, e-book.

16 AZEVÊDO, Roberto Carvalho de. O Brasil e o Mecanismo de Solução de Controvérsias da OMC. In: LIMA, Maria Lúcia Labate
A OMC também se mostrou capaz de desempenhar aquilo que talvez seja a sua principal tarefa que é limitar o protecionismo dos países em relação aos seus mercados internos. Esse fato ganha ainda mais relevo no contexto de uma crise financeira e econômica, como a que sobreveio sobre os EUA em 2008, pois, ao contrário de épocas anteriores, a crise não levou os Estados a fecharem seus mercados.

No entanto, em relação ao Brasil pesa atualmente um fator desfavorável nesse sentido. No início de 2014, o diretor-geral da OMC apresentou um relatório oficial em Genebra, que aponta o Brasil como campeão em medidas protecionistas no ano anterior (entre outubro de 2012 e novembro de 2013). . $^{17}$

De acordo com o documento, o Brasil "foi o país que mais adotou políticas contra produtos importados em todo o mundo" no ano de 2013, "com um total de 39 processos antidumping", conforme o relatório da organização ${ }^{18,}$ o que deu ao país o título de campeão em medidas protecionistas, o que reforça a sua imagem no exterior, notadamente na $\mathrm{EU}$, como um país que tem buscado medidas restritivas contra importações, v.g., elevando os impostos de importação (barreira tarifária) e concedendo isenção de impostos para empresas que fabriquem seus produtos dentro do mercado brasileiro.

No final de 2013, por ocasião de sua IX Conferência Ministerial, sob a direção geral do brasileiro Roberto Azevêdo, uma grande conquista da OMC foi conseguir concluir o primeiro acordo comercial global nos quase 20 anos de sua existência, na conferência realizada em Bali, na Indonésia. Embora o referido acordo consista num pacote modesto de medidas quando comparado às ambições iniciais da Rodada Doha ${ }^{19}$ (vide comentários

Mantovanini Padua; ROSENBERG, Barbara (Coords.). O Brasil e o Contencioso na OMC. Tomo I. São Paulo: Saraiva, 2009, e-book.

17 COLON, Leandro. OMC lista Brasil como líder em protecionismo. Londres. 2014. Disponível em: <http://www1. folha.uol.com.br/mercado/2014/02/1413705-omc-lista-brasilcomo-lider-em-protecionismo.shtml>. Acesso em 14: out. 2014.

18 VEJA. Brasil é o número $1 \mathrm{em}$ medidas protecionistas, diz OMC. 2014. Disponível em: < <ttp://veja. abril.com.br/noticia/economia/brasil-e-o-n-1-em-medidasprotecionistas-diz-omc>. Acesso em 14: out. 2014.

19 Em síntese, a Rodada Doha constitui atualmente o principal elemento do comércio mundial e também o seu grande desafio. Trata-se de exaustivas negociações iniciadas em 2001 no âmbito da OMC, entre os Estados-membros da organização, incluindo-se as maiores potências comerciais do mundo, visando a diminuição de barreiras comerciais, com foco no livre comércio. As negociações receberam o nome de Doha, capital do Qatar, pelo fato de ter sido nessa cidade que os países começaram a sua discussão. As conversas 
adiante), esse fato representou um significativo fôlego para a credibilidade da organização. $O$ acordo é importante porque constitui o primeiro realizado pela OMC desde o último acordo comercial global que havia sido realizado na Rodada do Uruguai, em 1994, ainda no âmbito do GATT, e pela primeira vez na história a organização chegou a um consenso, produzindo resultados.

Em síntese, o primeiro acordo global da organização envolve um esforço conjunto de 159 Estados-membros para simplificar os procedimentos para negócios internacionais. O pacote de Bali contém dez textos que estão divididos em três grandes temas: a desburocratização e facilitação do comércio, a agricultura e a promoção do desenvolvimento dos países mais pobres. ${ }^{20}$

Conforme notícia veiculada no jornal "Valor Econômico", de acordo com a Câmara Internacional de Comércio, o primogênito acordo tem o condão de gerar um incremento do comércio global de US\$ 1 trilhão e reduzir ainda entre $10 \%$ e $15 \%$ os custos de transação entre as empresas, podendo criar 21 milhões de empregos no planeta. ${ }^{21}$ No Brasil o acordo de Bali foi comemorado. Em nota oficial, o Ministério das Relações Exteriores afirmou que os resultados são "amplamente positivos" para o Brasil e terão a capacidade de permitir a implementação de "reformas" no país. ${ }^{22}$

\subsection{Os desarranjos e os desafios da OMC na atualidade}

No contexto de um mundo globalizado,

e negociações têm como ponto central a separação entre os países ricos e desenvolvidos e os maiores países em desenvolvimento (representados pelo G20), sendo os subsídios agrícolas o principal tema de controvérsia no âmbito das negociações, embora a agenda inicial da rodada conte com 21 temas amplos e complexos.

20 LANDIM, Raquel. É a hora de acabar com a utopia do consenso na OMC. Disponível em:

$<$ http://www1. folha.uol.com.br/colunas/raquellandim/2013/12/1382381-e-ahora-de-acabar-com-a-utopia-do-consenso-na-omc.shtml>. Acesso em: 15 out. 2014.

21 MOREIRA, Assis. OMC aprova em Bali primeiro acordo comercial global em décadas. Disponível em: < $<\mathrm{ttp}$ : / / w w . valor.com.br/internacional/3365324/omc-aprova-em-baliprimeiro-acordo-comercial-global-em-decadas $>$. Acesso em: 14 out. 2014.

22 BRASIL. Ministério das Relações exteriores. IX Conferência Ministerial da OMC. Disponível em:

$<\mathrm{h}$ t $\mathrm{t}$ p : / / www.itamaraty.gov.br/sala-de-imprensa/notas-a-imprensa/ixconferencia-ministerial-da-omc >. Acesso em: 14 out. 2014. a crescente internacionalização da economia decorrente principalmente da redução de barreiras ao comércio mundial, da maior velocidade das inovações tecnológicas e dos grandes avanços nas comunicações $^{23}$

tem gerado profundas mudanças no relacionamento comercial em âmbito mundial, demandando dos países mudanças efetivas na atuação no comércio internacional e como consequência exercendo pressão sobre a OMC, que hoje tem questionada a sua capacidade de promover entendimentos multilaterais e consequentemente cumprir os papéis para os quais foi vocacionada de maneira efetiva. ${ }^{24}$ Em verdade, há aqueles que vislumbram até um futuro esvaziamento da organização em razão do estado de coisas que se estabeleceu nos últimos anos.

Em um recente e sintético escrito intitulado "Desafios na OMC: discussão não deve ter influência ideológica" 25 , Rubens Barbosa aponta três desafios que os Estados-membros da OMC deverão enfrentar para recuperar a credibilidade e a relevância da organização para o comércio internacional: (i) retomar efetivamente as negociações da Rodada de Doha; (ii) tentar incluir

23 MARTINS, Eliane M. Octaviano. A sistemática de solução de controvérsias no âmbito da OMC. 2006. Disponível em:

<http://www.planalto.gov.br/ccivil_03/revista/Rev_40/artigos/ art_Eliane.html>. Acesso em 14 out. 2014.

24 A doutrina aponta que a OMC surgiu para enfrentar diversos problemas para os quais não foram encontradas soluções adequadas no âmbito do GATT: “a) a necessidade de efetiva integração de todos os países ao sistema proposto pelo GATT e demais Acordos Multilaterais; b) uma análise sobre o crescimento dos produtos de alta tecnologia e seus reflexos nos países excluídos; c) a questão da propriedade intelectual e das marcas e patentes internacionais ante o aumento da pirataria e da contrafação; d) a importância crescente dos subsídios à exportação como instrumento de política pública em determinados países; e) o enorme desenvolvimento do comércio de serviços, capaz de suplantar as transações entre mercadorias; f) as características peculiares do novo capital, a partir da globalização econômica, e a política de investimentos internacionais; g) a ausência de um ambiente permanente de negociações e de mecanismos de solução de controvérsias." (CAPARROZ, Roberto. Comércio internacional esquematizado. São Paulo: Saraiva, 2012, e-book).

25 BARBOSA, Rubens Antônio. Desafios da OMC. Disponível em: $<$ http://oglobo.globo.com/opiniao/desafios-na-omc-11702806>. Acesso em: 14 out. 2014. Rubens Antônio Barbosa foi embaixador do Brasil em Washington (1999-2004). É presidente do Conselho Superior de Comércio Exterior (Coscex) da Fiesp. É também articulista dos jornais "O Estado de São Paulo" e "O Globo", sendo também editor chefe da revista "Interesse Nacional". É autor dos livros "Panorama Visto de Londres", sobre política externa e econômica; "Integração Econômica da América Latina" e "The Mercosur Codes". 
na $\mathrm{OMC}$ os acordos regionais e bilaterais e suas regras; (iii) e reformar a governança da instituição.

Nos termos do artigo 28 do GATT, as partes contratantes podem realizar negociações com a finalidade de diminuir as tarifas de importação e promover a abertura dos mercados. No âmbito do GATT, foram realizadas pelos países membros, oito Conferências Comerciais Multilaterais, também conhecidas como "rodadas", sendo que a mais importante certamente foi a Rodada do Uruguai, que culminou com a criação da OMC, como já delineado.

Já no âmbito da OMC, as reuniões dos Estadosmembros em rodadas de negociações ocorrem por meio das Conferências Ministeriais, conforme já visto. A organização já realizou diversas rodadas e teve como divisor de águas e momento mais importante pós Rodada do Uruguai, o encontro promovido na cidade de Doha, capital do Qatar, em novembro de 2001. Porém, antes disso, três outras Conferências foram realizadas, com resultados variados (Cingapura - 1996; Genebra - 1998; Seattle - 1999). Acerca da Rodada de Doha, Caparroz explica que

O momento mais importante pós-Rodada Uruguai ocorreu em Doha, durante a Quarta Conferência Ministerial da Organização Mundial do Comércio, realizada entre 9 e 14 de novembro de 2001. Em meio à perspectiva de diminuição do crescimento das relações comerciais internacionais, agravada pela preocupação global causada pelos ataques terroristas em 11 de setembro, os países elegeram como ponto fundamental das negociações a necessidade de maior inserção dos países em desenvolvimento. $\mathrm{O}$ objetivo era a um só tempo essencial e ambicioso, pois precisava alcançar soluções para o acesso a mercados, regras mais balanceadas entre países desenvolvidos e menos desenvolvidos, assistência técnica contínua e financeiramente sustentável, além da necessidade de implantação de programas de capacitação efetivos para o desenvolvimento das economias mais frágeis. Tudo isso somado à eterna questão dos subsídios agrícolas, o grande nó das negociações multilaterais desde a criação do GATT. Ao término da conferência, foi produzida pelos signatários uma declaração ministerial que definiu a criação de uma nova rodada de negociações, a primeira no âmbito da $O M C$, que foi batizada de Rodada do Desenvolvimento. (grifo nosso) ${ }^{26}$

A atual rodada de negociações, denominada Rodada do Desenvolvimento é a primeira oficialmente conduzida sob os auspícios da OMC. Foi construída tendo como fundamento primordial a maior participação dos países em desenvolvimento no comércio internacional e o livre acesso ao mercado mundial a todos os participantes da organização, o que implica consequentemente a necessidade de alguns países, notadamente aqueles ricos e desenvolvidos, abrirem suas economias, a fim de superar-se o protecionismo dos mercados internos, v.g., por meio da redução de tarifas alfandegárias e outras barreiras comerciais. Manfred Elsig e Cédric Dupont explicam que

as negociações sobre questões distributivas são naturalmente caracterizadas por períodos de progresso e de estagnação. Portanto, não é incomum que, de tempos em tempos, apareçam impasses acerca das negociações sobre a maneira como os países abrem as suas economias ao comércio. ${ }^{27}$

A Rodada Doha contou com uma agenda inicial ambiciosa, que envolvia 21 temas amplos e complexos. Assim, diversos temas correlatos à temática principal são objeto dos debates e impasses no bojo dessa rodada de negociações (v.g., serviços, bens industriais, investimentos, políticas de concorrência, antidumping e subsídios, acordos comerciais regionais, solução de controvérsias, comércio e meio ambiente, comércio eletrônico etc.), sendo a agricultura certamente um dos aspectos mais espinhosos a serem enfrentados. ${ }^{28}$

26 CAPARROZ, Roberto. Comércio Internacional Esquematizado. São Paulo: Saraiva, 2012, e-book.

27 ELSING, Manfred; DUPONT, Cédric. Persistent Deadlock in Multilateral Trade Negotiations: The Case of Doha. In: NARLIKAR, Amrita; DAUNTON, Martin; STERN, Robert M. The Oxford Handbook on the World Trade Organization. New York: Oxford University Press, 2012, e-book. "Negotiations over distributive issues are naturally characterized by periods of progress and of stagnation. Therefore, it is not unusual that, from time to time, negotiations over the way countries open their economies to trade appear deadlocked".

28 Não há dúvidas de que um dos maiores pontos de discórdia nas discussões e negociações ocorridas no âmbito da OMC é a agricultura, assunto que acarretou uma divisão entre os países industrializados e as nações em desenvolvimento, tais como o Brasil. Apenas para se ter uma breve noção da problemática envolvendo a agricultura, algumas perguntas que constituem o núcleo dos 
Tudo isso acabou por transformar a Rodada de Doha na mais complexa negociação multilateral da história, o que explica, em parte, o fato de até o presente momento não se ter chegado a qualquer conclusão, estando praticamente paralisada desde então. ${ }^{29}$ Alguns especialistas em OMC, como o professor Simon J. Evenett, da Universidade St. Gallen, na Suíça, afirma que a Rodada Doha está morta, embora ninguém queira dizer isso em voz alta. ${ }^{30}$

Portanto, retomar de modo efetivo as negociações dessa rodada parece ser o primeiro grande obstáculo a ser enfrentado pela organização, principalmente diante do quadro atual de baixo crescimento econômico e do alto nível de desemprego na Europa, bem como em razão de acordos regionais e bilaterais que, de certo modo, propiciam uma zona conforto para os países desenvolvidos no âmbito de suas negociações comerciais, o que faz com que seus dirigentes manifestem certo desinteresse pelas negociações no domínio da OMC, como já demonstraram os dirigentes americanos e europeus.

De outro lado, países em desenvolvimento dificilmente tenderão a abrir mão de suas agendas de desenvolvimento e de interesses específicos, especialmente "quanto à redução ou eliminação dos

debates no âmbito da OMC são elucidativas: os países ricos devem abolir os subsídios que concedem a seus agricultores? Os países em desenvolvimento podem cobrar tarifas de importação para proteger seus próprios produtos? Conforme já indicou o atual ministro das Relações Exteriores, Luiz Alberto Figueiredo, para o Brasil, a retomada das negociações da Rodada Doha depende da inclusão na pauta das distorções comerciais na agricultura. Disponível em:

$<$ http://opiniao.estadao.com.br/noticias/geral,desafios-para-obrasil-na-omc-imp-,1134295>. Acesso em: 14 out. 2014.

Para um aprofundamento na temática da agricultura no contexto da OMC vide: RODRIGUES, Tatiana S. Fukuda; PAULA, Nilson M. de. A agricultura nas negociaçoes multilaterais da Rodada Doba e suas implicações para o Brasil. Disponível em:

$<$ http://ojs.c3sl.ufpr.br/ojs/index.php/economia/article/ viewFile/12297/8514>. Acesso em: 14 out. 2014.

29 Para uma visão completa acerca dos impasses e dos impedimentos que têm paralisado a Rodada de Doha, sob uma perspectiva da Teoria dos Jogos, vide elucidativo escrito de Manfred Elsig e Cédric Dupont: Persistent Deadlock in Multilateral Trade Negotiations: The Case of Doha. In: NARLIKAR, Amrita; DAUNTON, Martin; STERN, Robert M. The Oxford Handbook on the World Trade Organization. New York: Oxford University Press, 2012, e-book.

30 EVENETT, Simon J. The Doha Round Impasse. 2012. Disponível em:<http://graduateinstitute.ch/files/live/sites/iheid/ files/shared/summer/WTO2012/protected/Evenett_Doha_ Round_Impasse_paper_March_2012\%20revised.pdf >. Acesso em: 14 out. 2014. créditos à produção e aos subsídios à exportação" 31 , havendo até quem afirma que a Rodada de Doha está morta.

Conforme delineado anteriormente, o segundo problema a ser enfrentado pela organização, uma vez retomadas as negociações, será trazer para o plano das negociações multilaterais os acordos comerciais que estão sendo discutidos e travados fora do âmbito da organização. Atualmente a OMC está sob forte pressão por estar enfrentando a concorrência de acordos bilaterais e mega-acordos regionais, articulados e concluídos no âmbito de países e blocos regionais específicos, a exemplo daqueles que têm sido constituídos entre EUA e países asiáticos e entre EUA e União Europeia. Desse modo, tentar trazer para o âmbito da organização estes acordos regionais e bilaterais e as suas regras, que para alguns vão "muito além das existentes hoje no âmbito da $\mathrm{OMC}^{\prime 32}$, é realmente um grande obstáculo a ser superado. Rubens Barbosa, comentando essa questão ressalta que

\begin{abstract}
Mais de 500 acordos regionais e bilaterais estão em discussão e 345 foram notificados à Organização e estão em vigor. A função de monitoramento desses acordos, um dos pilares da OMC, no entanto, não está sendo exercida por falta de condições técnicas e políticas. Como multilateralizar as concessões e as regras negociadas fora da entidade e que ultrapassam os limites hoje vigentes, como as chamadas de OMC plus (serviços, barreiras técnicas ou propriedade intelectual), bem assim as que tratam de temas que estão fora do marco da OMC, como investimento, concorrência, meio ambiente, padrões trabalhistas? As negociações de acordos preferenciais de comércio e dos megaacordos regionais não se restringem à redução de tarifas de importação, hoje muito reduzidas, mas focam um quadro regulatório que impacta diretamente o intercâmbio de bens e serviços, como barreiras técnicas, sanitárias e fitossanitárias, mudança climática, eficiência energética, direitos humanos, padrões (standards) e economia digital, entre outros. ${ }^{33}$
\end{abstract}

31 BARBOSA, Rubens Antônio. Desafios da OMC. Disponível em: $<$ http://oglobo.globo.com/opiniao/desafios-na-omc-11702806>. Acesso em: 14 out. 2014.

32 BARBOSA, Rubens. Desafios para o Brasil na OMC. Disponível em: <http://opiniao.estadao.com.br/noticias/geral,desafios-parao-brasil-na-omc-imp-,1134295>. Acesso em: 14 out. 2014.

33 BARBOSA, Rubens. Desafios para o Brasil na OMC. Disponível 
Verifica-se inclusive que a $\mathrm{OMC}$, enquanto órgão harmonizador do comércio internacional pretende ajudar os seus membros a seguirem padrões comerciais que satisfaçam seus interesses econômicos, enquanto, ainda que em segundo plano, produza a interação entre o comércio mundial e outras áreas como os direitos humanos e o meio ambiente. Portanto, um dos grandes desafios atuais da OMC está em alcançar um comércio livre, de acordo com os postulados do desenvolvimento sustentável, respeitando os diferentes níveis de desenvolvimento econômico dos Estados. Percebe-se assim que enquanto o antigo GATT tinha como um de seus objetivos principais incentivar ao máximo a utilização dos recursos mundiais, frutos da liberalização gradual do comércio internacional por meio da eliminação das barreiras comerciais, a OMC, conforme estabelecido em seu preâmbulo, inova ao incorporar novas temáticas ao comércio.

Como terceiro desafio, para enfrentar as questões relativas à retomada das negociações de Doha e a inclusão dos acordos e regras estabelecidos fora da OMC, prega-se a necessidade de reforma e modernização da organização para atender, de maneira satisfatória, às expectativas e reclamos de um comércio internacional intrincado e complexo.

É certo que as instituições internacionais como a OMC podem ser pensadas, concebidas e estruturadas sob diversas formas; contudo, o fator mais importante que se deve ter em mente é que essas instituições devem ter como objetivo principal a busca pela agregação dos interesses dos vários atores envolvidos nas negociações. Desde as preciosas contribuições de Keohane ${ }^{34}$ para a escola liberal, as instituições têm sido conceituadas como "plataformas que permitem a cooperação para ocorrerem" e, segundo o autor, essas instituições "existem porque delas poderia razoavelmente se esperar um aumento no bem-estar de seus criadores". ${ }^{35}$

É certo que o "bem-estar" dos Estados-membros da OMC depende da cooperação entre eles para a consecução de interesses comuns, mas, por outro lado,

em: <http://opiniao.estadao.com.br/noticias/geral,desafios-parao-brasil-na-omc-imp-,1134295>. Acesso em: 14 out. 2014.

34 KEOHANE, Robert O. After Hegemony: Cooperation and Discord in the World Political Economy. Princeton: Princeton University Press, 1984.

35 KEOHANE, Robert O. After Hegemony: Cooperation and Discord in the World Political Economy. Princeton: Princeton University Press, 1984, p. 80. "institutions exist because they could have reasonably been expected to increase the welfare of their creators" essa cooperação depende diretamente da satisfação (ou possibilidade de satisfação) dos interesses em jogo. Atualmente, para que a OMC seja capaz de promover de maneira satisfatória um ambiente onde interesses multilaterais diversos sejam convergidos para um denominador comum, precisa caminhar, no sentido de uma reorganização estrutural, bem como revisitar e modificar algumas de suas instituições tais como a regra da decisão por consenso (Art. IX, 1, do Acordo Constitutivo da OMC), o principio do single undertaking (Art. II, 2 e 3, do Acordo Constitutivo da OMC) e o tratamento especial e diferenciado para países em desenvolvimento (estabelecido no Art. XXVIII e na Parte IV do GATT - 1994). Em relação a esse ponto específico, Rubens Barbosa afirma que

Tal como funciona hoje, a OMC não está preparada para reagir às demandas da globalização, da evolução do comércio global e da revolução das cadeias produtivas, responsável por $56 \%$ do intercâmbio comercial e $72 \%$ dos serviços no mundo [...]. Com 160 países-membros, as decisões por consenso serão cada vez mais difíceis e formas alternativas para formar consenso pela maioria terão de ser encontradas; a manutenção do tratamento especial e diferenciado aos países em desenvolvimento já está sendo questionada pelos desenvolvidos para países como a China, o Brasil, a Índia e outros; o single undertaking está sendo um fator impeditivo de avanço, como se viu na Rodada Doha. Ao lado desses itens, a possibilidade de acordos plurilaterais (abertos ou restritos) terá de ser discutida para permitir que quem quiser participar possa fazê-lo sem esperar que todos venham a participar. Hoje existem dois acordos plurilaterais em negociação fora da OMC - que não permite esse tipo de negociação - o de Serviços e o de Tecnologia da Informação. O funcionamento de alguns órgãos da OMC terá de ser revisto para aumentar a eficiência e a aplicação das decisões. Um desses órgãos é o comitê que examina os acordos regionais. Caso haja um efetivo interesse em incorporar os acordos negociados fora da OMC, o comitê deverá ser transformado num conselho para aumentar seu peso político. Finalmente, em função da importância dos temas e de sua relevância para os operadores privados, deveria ser considerada a participação do setor privado. A OMC é uma instituição intergovernamental sem a presença 
de representantes empresariais, por isso alguma forma de participação privada será importante para influir no processo de negociação. ${ }^{36}$

Manfred Elsig e Cédric Dupont, ao comentarem a organização estrutural atual da OMC e suas instituições, explicam em feliz síntese que

As instituições tornam possíveis os acordos e lhes dão credibilidade. Uma vez que Estados obtém incentivos para se aproveitarem ou mesmo renunciarem a acordos anteriores, o projeto exato (e nível de legalização) faz-se importante para o entendimento do desejo ex ante e ex post de adesão. Pode-se também abordar as instituições internacionais por uma perspectiva realista. Em especial, os analistas que seguem a tradição do institucionalismo neorrealista focam em como regimes internacionais afetam a distribuição dos benefícios e custos da interação estatal. As instituições têm consequências distributivas e podem ser utilizadas como instrumentos para que sejam obtidos e mantidos os ganhos assimétricos. Elas podem ainda auxiliar mais amplamente no controle do comportamento de outros atores, domésticos e internacionais. Podemos diferenciar um número de explanações pela forma como diferentes tipos de "instituições" afetam os resultados. Primeiramente, encontramos explanações que têm o foco na forma como os procedimentos de negociação são definidos. Isso inclui as instituições que determinam quem tem direito a um assento à mesa nas discussões mais importantes relacionadas ao tema central e como os procedimentos de tomada de decisão (por votação ou consenso) devem ser aplicados. Um fator constituinte no contexto da OMC - em adição à busca de consenso - é o compromisso único, fator este em que todos os temas são ligados e "nada é acordado até que tudo seja acordado". A escolha de tais 'micro instituições' tem implicações importantes para as condições sob as quais as colisões são construídas e afetam integralmente as negociações. Além disso, o papel designado aos presidentes dos grupos de negociação ou ao Diretor Geral e ao Secretariado também pode ser importante. Em segundo lugar, as instituições internacionais podem repercutir no nível

36 BARBOSA, Rubens. Desafios para o Brasil na OMC. Disponível em: <http://opiniao.estadao.com.br/noticias/geral,desafios-parao-brasil-na-omc-imp-,1134295>. Acesso em: 14 out. 2014. doméstico. Trabalhos recentes têm dado atenção a como o processo de regulamentação no contexto da OMC tem afetado o equilíbrio entre forças de grupos de interesse nesse nível doméstico. Ademais, uma vez que a crescente regulamentação no âmbito da OMC afeta a aplicação da lei doméstica, as partes estão se tornando cada vez mais relutantes em assumir novos compromissos. A literatura mostra que algumas instituições são mais propensas a bloquear as negociações (v.g., formação de consenso versus votação majoritária), ao passo que mudanças institucionais (v.g., por meio da formação de coalisão e invenções processuais) possam acontecer como condição necessária para o avanço das negociações. Enquanto alguns podem considerar tais mudanças mais como sendo parte das táticas e estratégias dos atores do que fatores contextuais ou estruturais em si, nós as discutimos nessa sessão tendo em conta que os tipos de microinstituições mencionados acima são estáticos e não se alteram da noite para o dia.". 37

37 ELSING, Manfred; DUPONT, Cédric. Persistent Deadlock in Multilateral Trade Negotiations: The Case of Doha. In: NARLIKAR, Amrita; DAUNTON, Martin; STERN, Robert M. The Oxford Handbook on the World Trade Organization. New York: Oxford University Press, 2012, e-book. "Institutions make deals possible and credible. As states face incentives to free-ride or to renege on past agreements, the exact design (and level of legalization) is important for understanding ex ante and ex post willingness to commit. International institutions can also be approached within a realist perspective. In particular, analysts following the tradition of neorealist institutionalism focus on how international regimes affect the distribution of costs and benefits of state interaction. Institutions have distributional consequences, and can be used as devices to seek and maintain asymmetric gains. They can more broadly help control other actors' behaviour, both at home and abroad. We can differentiate a number of explanations as to how various types of 'institutions' affect outcomes. First, we find explanations that focus on the way negotiation procedures are defined. These include institutions that determine who has a seat at the table in the most important subject-related discussions and how the dominating modes of decision-making procedures (voting or consensus) are to be applied. A constituent feature in the WTO context - in addition to consensus-seeking - is the single undertaking, where all issues are linked and 'nothing is agreed until everything is agreed'. The choice of such 'micro-institutions' has important implications for the conditions under which coalitions are built, and affects overall negotiations. Furthermore, the role assigned to the chairs of the respective negotiation groups, or to the DG and the Secretariat staff, may also matter. Second, international institutions may reverberate at the domestic level. Recent work has focused on how legalization in the WTO context has affected the balance of interest group powers at home. Moreover, given that increasing legalization affects enforcement, parties are becoming more reluctant to commit to new obligations. The literature shows that some institutions are more likely to lead to deadlock (e.g. consensus decision-making versus 
O que se pode aferir é que um dos maiores problemas a serem enfrentados pela $\mathrm{OMC}$, no tocante à necessidade de uma restruturação organizacional, institucional e normativa, refere-se ao processo de tomada de decisões nas negociações (processo decisório). Como se sabe, a OMC manteve a prática de tomada de decisões por consenso que prevalecia no GATT, com direito a voto de todos os membros. ${ }^{38}$

Apesar da existência dos procedimentos de votação elaborados, a maioria das decisões do GATT é, na prática, tomada com base no consenso. Essa prática do GATT foi codificada no artigo IX. ${ }^{39}$, do Acordo que instituiu a OMC.40

Para os Estados-membros da OMC, a importância do consenso reside no fato de se possibilitar que todos os membros, mediante concessões recíprocas, possam alcançar um denominador comum.

majority voting), while institutional changes (e.g. through coalitionbuilding and procedural inventions) might act as a necessary condition for advancing negotiations. Whereas one could consider these changes to be part of actors' strategies and tactics rather than structural or contextual factors, we discuss them under this section given that the types of micro-institutions mentioned above are sticky and do not change overnight".

38 Dispõe o artigo $9^{\circ}, 1$, de seu documento constitutivo que "A OMC continuará a prática de processo decisório de consenso seguida pelo GATT 1947 (1). Salvo disposição em contrário, quando não for possível adotar uma decisão por consenso, a materna em questão será decidida por votação. Nas reuniões da Conferência Ministerial e do Conselho Geral cada Membro da OMC terá um voto. Quando as Comunidades Europeias exercerem seu direito de voto terão o número de votos correspondente ao número de seus Estados-Membros (2) que são membros da OMC. As decisões da Conferência Ministerial e do Conselho Geral serão tomadas por maioria de votos salvo disposição em contrário do presente Acordo ou do Acordo multilateral de comércio pertinentes (3)."

39 "A OMC manterá a prática da tomada de decisões por consenso seguida por força do GATT de 1947 (ver nota 1). Salvo disposição em contrário, nos casos em que não for possível chegar a uma decisão por consenso, a questão em causa será decidida por votação. Nas reuniões da Conferência Ministerial e do Conselho Geral, cada Membro da OMC disporá de um voto. Nos casos em que as Comunidades Europeias exerçam o seu direito de voto, disporão de um número de votos igual ao número dos seus Estados membros (ver nota 2) que sejam Membros da OMC. As decisões da Conferência Ministerial e do Conselho Geral serão adoptadas por maioria dos votos expressos, salvo disposição em contrário prevista no presente Acordo ou no acordo comercial multilateral pertinente (ver nota 3)."

40 NARLIKAR, Amrita. The World Trade Organization: a very short introduction. New York: Oxford University Press, 2005, p. 44. "Despite the existence of elaborate voting procedures, most decisions in the GATT were in practice taken on the basis of consensus. This GATT practice has been codified in Article IX.1 of the Agreement establishing the WTO."
Mesmo que não haja o consenso, determinadas questões podem ser resolvidas por votação, em que as decisões são acolhidas por maioria de votos emitidos, sendo que cada país representa um voto $\left(\operatorname{art.} 9^{\circ}, 1\right) .^{41}$ Contudo, apesar da possibilidade de votação, é rara a ocorrência desse mecanismo no âmbito da OMC, assim como era à época do GATT. Isso porque é muito forte e prevalece entre os Estados-membros a ideia de consenso, uma vez que as partes contratantes são dotadas de soberania, e essa prerrogativa (de votação) não se coaduna com a noção democrática de se adotar decisões mediante maioria. Acerca da regra do consenso, Bernard M. Hoekmanis e Petros C. Mavroidis explicam que

o consenso não significa unanimidade. Significa
que nenhuma delegação representada em uma
reunião objetou a uma proposta. Chegar a um
consenso pode ser um processo complexo que vai
requerer ainterconexão de temas eassuntos. A regra
do consenso reforça as tendências conservadoras
no sistema. Propostas para mudança podem ser
adotadas apenas se não sofrerem oposição. Embora
possa potencializar a estagnação, o consenso ajuda
a realçar a legitimidade das decisões. ${ }^{42}$

Conforme se pode aferir pelas colocações dos autores, a regra do consenso é uma faca de dois gumes, pois, embora propicie maior legitimidade para as decisões tomadas pelos membros da OMC, ao mesmo tempo tem o potencial de travar as negociações, paralisar as discussões e impedir a elaboração de acordos multilaterais no âmbito da organização. Em

41 De acordo com o documento constitutivo da OMC, existem restrições quanto aos temas que podem ser objeto de votação, de modo que as grandes e importantes questões negociadas não podem ser decididas sem o devido consenso. Para quatro situações específicas, o Acordo Constitutivo da Organização Mundial do Comércio prevê votação: 1) adoção de uma interpretação para qualquer um dos acordos (maioria de $3 / 4$ dos membros); 2 ) isenção de uma obrigação (maioria de $3 / 4$ dos membros); 3 ) emenda das disposições do acordo geral (consenso ou maioria de $2 / 3$ dos membros), segundo a natureza da disposição considerada; 4) admissão de um novo membro (maioria de $2 / 3$ dos membros) na Conferência Ministerial.

42 HOEKMAN, Bernard M.; MAVROIDIS, Petros C. The World Trade Organization: law, economics, and politics. Abingdon: Routledge, 2007, p. 25. "Consensus does not mean unanimity. It signifies that no delegation represented in a meeting objects to a proposal. Achieving consensus can be a complex process, requiring issue linkages. Consensus reinforces conservative tendencies in the system. Proposals for change can be adopted only if unopposed. Although it creates the potential for paralysis, consensus helps enhance the legitimacy of decisions". 
verdade, esse tem sido o quadro que se pode verificar desde o início das negociações na Rodada de Doha, evidenciado, dentre tantos outros fatores, pelo fato de somente após quase 20 anos de existência, a OMC foi capaz de concluir o seu primeiro acordo multilateral, conforme já delineado anteriormente.

O que se verifica é que pela regra do consenso, um único país pode paralisar as negociações sobre determinado tema e isso compromete sobremaneira a margem de manobra da OMC, pois obter o consenso dos atualmente 160 Estados-membros que integram a organização é sem dúvida uma tarefa hercúlea. Para alguns a regra do consenso é uma utopia. Marcos Jank, diretor de relações com o mercado da BRF e um dos maiores especialistas brasileiros em negociações comerciais, afirma que

a OMC precisa abandonar a utopia de tomar decisões por consenso. 'No antigo Gatt (antecessor da OMC), um grupo pequeno de países tomava todas as decisões. Hoje é impossível colocar 160 países de acordo. O mundo mudou. ${ }^{43}$

Os efeitos produzidos pela regra do consenso sem dúvida reverberam larga e negativamente na imagem da organização e sua capacidade de gestão do comércio internacional multilateral, notadamente naquilo que toca à produção normativa internacional sobre essa temática, já que o que se nota nesse particular é que a legislação do comércio internacional não se desenvolveu significativamente nos últimos 20 anos, o que não pode ser dito em relação ao desenvolvimento do próprio comércio internacional.

Nesse ponto, o que se conclui é que a OMC precisa superar a regra do consenso, pois, dado o número cada vez maior de participantes, as decisões por esse caminho se tornarão cada vez mais difíceis, de modo que se torna imperioso para a organização buscar alternativas para a obtenção do consenso pela maioria.

Outro problema que se apresenta e que carece de uma devida atenção e reforma no âmbito da OMC diz respeito ao princípio do single undertaking (ou princípio do compromisso único). De acordo com ele, as negociações no âmbito da organização exigem concordância de todos os Estados-membros em relação

43 FOLHA DE SÃO PAULO. É a hora de acabar com a utopia do consenso na OMC. Disponível em: $<$ http://www1. folha.uol.com.br/colunas/raquellandim/2013/12/1382381-e-ahora-de-acabar-com-a-utopia-do-consenso-na-omc.shtml>. Acesso em: 15 out. 2014. aos temas propostos, sem possibilidade de escolhas ou adesões parciais. Conforme esse princípio, nada de "geral" será aprovado pela organização a menos que cada acordo individual esteja decidido. De acordo com Roberto Caparroz, o

single undertaking consiste na negociação de um pacote de metas; ou seja, enquanto não houver definição para qualquer dos pontos negociados, o acordo, como um todo, não se materializa. ${ }^{44}$

Praticamente todos os itens de uma negociação são parte de um todo indivisível e um pacote e não podem ser acordados separadamente. Assim, nada está acordado até que tudo esteja acordado.

Em tese, a ideia do single undertaking parece salutar, pois tem o condão de incentivar a obtenção de concessões mútuas e a reciprocidade de tratamento entre os membros da organização. Celso Lafer, tecendo comentários sobre a essencialidade das normas da OMC, afirma que o mercado internacional não opera no vazio, mas requer uma ordem normativa e explica que nesse sentido

$$
\begin{aligned}
& \text { o single undertaking de suas normas limita a } \\
& \text { competência discricionária das soberanias } \\
& \text { nacionais dos membros da OMC para promover } \\
& \text { o seu interesse comum, expandindo a produção } \\
& \text { e o comércio de bens e serviços, como se lê no } \\
& \text { preâmbulo do Acordo de Marraqueche. Essa } \\
& \text { expansão é concebida como propícia ao bem-estar } \\
& \text { geral e consequentemente vista como geradora de } \\
& \text { um bem público internacional. }
\end{aligned}
$$

Contudo, na prática, o que se tem verificado é que o princípio tem conduzido as negociações a um beco sem saída, já que se não houver uma definição para qualquer dos pontos negociados, acordos, como um todo, não se materializam, o que acaba também por travar as negociações multilaterais e a criação de uma legislação dinâmica para acompanhar relações comerciais internacionais também dinâmicas. De outro ângulo, o single undertaking também pode servir como uma espécie de subterfúgio para aqueles países que não vêm os seus interesses nas negociações atendidos, pois ao oporemse à negociação de um determinado tema, sabem que

44 CAPARROZ, Roberto. Comércio Internacional Esquematizado. São Paulo: Saraiva, 2012, e-book.

45 LAFER, Celso. A OMC e a regulamentação do comércio internacional: uma visão brasileira. Porto Alegre: Livraria do Advogado, 1998, p. 145. 
acabarão impedindo a conclusão de determinado acordo de um modo geral.

Conforme se afere, o princípio constitui, em verdade, um fator impeditivo de avanço nas negociações multilaterais e, portanto, é outro ponto que carece de uma reforma e exige superação por parte da OMC, pois os resultados de determinadas negociações não podem ficar adstritos ao sucesso ou fracasso de outras negociações. É preciso avançar com as negociações que se mostrem menos intrincadas e complexas, ainda que não se chegue a um acordo sobre aquelas que se apresentam mais problemáticas, postergando o tratamento dessas últimas para um momento ulterior.

Ao lado da regra do consenso e do princípio do single undertaking, outro instituto que merece atenção dentro do sistema normativo da OMC é o tratamento especial e diferenciado (SDT) para países em desenvolvimento (PEDs), ou seja, aqueles com grau de desenvolvimento inferior e, portanto, diversos dos países desenvolvidos.

No sistema internacional, essa discussão sempre teve grande relevância no comércio internacional, pois há muito tempo chegou-se à conclusão de que um tratamento normativo uniforme para todos os países, independentemente do seu grau de desenvolvimento, traz mais prejuízos do que benefícios ao sistema como um todo. Assim, o debate acerca da necessidade de um tratamento que encare os Estados-membros da OMC, de acordo com o seu grau de desenvolvimento, isto é, de modo diferenciado, flexibilizando o conceito de isonomia ${ }^{46}$, parece estar superado.

Nesse contexto, o tratamento especial e diferenciado foi concebido, ainda no âmbito do GATT, almejando a promoção do desenvolvimento daqueles países considerados mais atrasados, a fim de proporcionar a sua inserção no comércio internacional em um ambiente de relações comerciais mais maleáveis. Além disso, a Parte IV do GATT também beneficiou os países em desenvolvimento no sentido de possibilitar a adoção de medidas domésticas que possam apoiar seu desenvolvimento nacional. Também não há dúvidas de que esse mecanismo constitui um instrumento que

$46 \mathrm{Na}$ análise do princípio da isonomia no âmbito da OMC, especificamente sobre essa temática, deve ser analisado levandose em consideração as peculiaridades e diferenças geográficas, econômicas, históricas, sociais e culturais, dentre muitas outras, existentes entre os Estados que fazem parte do sistema multilateral de comércio internacional, de modo que não pode conceber exigências idênticas a todos os Estados quando estes guardam diferenças tão profundas entre si. auxilia os países em desenvolvimento a adquirirem capacidade legal e institucional para cumprir com suas obrigações de liberalização comercial. A cláusula da nação mais favorecida certamente é um reflexo desse tratamento.

Foge ao escopo do presente trabalho o estudo aprofundado dessa temática. ${ }^{47}$ No entanto, cumpre salientar que a aplicação dessa normativa consolidada no âmbito da organização não está livre de objeções e críticas. Um dos maiores problemas enfrentados nessa temática é a construção do conceito de tratamento especial e diferenciado, os limites de sua aplicação, bem como os impactos da sua efetivação para o desenvolvimento dos países e no sistema do comércio internacional de um modo geral. Quem são os países destinatários do tratamento especial e diferenciado? Como identificar dentro do conceito de diferenciação ou graduação, quem são os países que podem se beneficiar desse tipo de tratamento? Eduardo Saldanha explica que

O problema prático no sistema GATT/OMC é que
em toda a história nunca se alcançou um consenso
sobre uma definição de país em desenvolvimento, o
que leva a uma dificuldade de congregar os anseios
de todos quanto à possibilidade de diferenciação. ${ }^{48}$

Essa complexidade fatalmente leva à politização do debate entre os Estados-membros da OMC. Eduardo Saldanha exemplifica essa questão aduzindo que

países como México e República da Coreia, que se uniram recentemente à Organização para Cooperação e Desenvolvimento Econômico (OCDE), estão pouco dispostos a mudar a sua designação em razão da questão política associada ao status do país na OMC, estejam eles fazendo ou não uso do tratamento especial e diferenciado. ${ }^{49}$

47 Para um estudo aprofundado sobre a temática vide: SALDANHA, Eduardo. Desenvolvimento e Tratamento Especial $e$ Diferenciado na $O M C$ : uma abordagem sob a perspectiva da doutrina do stare decisis - Parte II. Disponível em: < http:/ / www2.pucpr.br/ $\mathrm{reol} /$ index.php/direitoeconomico?dd99 $=$ pdf\&dd1 $=7547>$. Acesso em: 16 out. 2014.

48 SALDANHA, Eduardo. Desenvolvimento e Tratamento Especial e Diferenciado na $O M C$ : uma abordagem sob a perspectiva da doutrina do stare decisis - Parte II. Disponível em: < http:/ /www2.pucpr.br/ $\mathrm{reol} /$ index.php/direitoeconomico?dd $99=$ pdf\&dd $1=7547>$. Acesso em: 16 out. 2014.

49 SALDANHA, Eduardo. Desenvolvimento e Tratamento Especial e Diferenciado na OMC: uma abordagem sob a perspectiva da doutrina do stare decisis - Parte II. Disponível em: < http://www2.pucpr.br/ $\mathrm{reol} /$ index.php/direitoeconomico?dd99=pdf\&dd1 $=7547>$. Acesso em: 16 out. 2014 . 
Outro exemplo do que está a se falar é o questionamento por parte de países desenvolvidos acerca da manutenção do tratamento especial e diferenciado dispensado aos países em desenvolvimento como China, Brasil e Índia, dentre outros. ${ }^{50}$

Assim, embora seja nítido que o tratamento especial e diferenciado constitua uma tentativa de correção de assimetrias do comércio internacional, visando atenuar as disparidades econômicas existentes entre os países participantes da OMC, notadamente por meio da introdução de tratamentos preferenciais em favor das nações que ainda não atingiram um nível de desenvolvimento suficientemente elevado para fazer frente às grandes potências econômicas, uma reestruturação e reavaliação desse mecanismo pelos Estados-membros da organização deve ocorrer a fim de que se possa avançar com as negociações no âmbito da OMC.

Somando-se às questões tratadas até aqui, vale ainda destacar que, sob o ponto de vista de Bernard M. Hoekmanis e Petros C. Mavroidis, há outros três grandes desafios que os membros da OMC devem enfrentar:

(1) o alargamento da cooperação multilateral para o âmbito das políticas domésticas "intrafronteiras"; (2) a abordagem das preocupações dos países em desenvolvimento quanto ao fato de o sistema comercial ser "desequilibrado"; e (3) lidar com a proliferação de acordos preferenciais de comércio. Nenhum desses desafios são novos. ${ }^{51}$

Conforme se nota, os Estados-membros da OMC precisam envidarem seus esforços a fim de alargarem a cooperação multilateral para o âmbito das políticas domésticas dos Estados ("por trás das fronteiras". Os países desenvolvidos precisam dar atenção e abordarem de maneira responsável as preocupações dos países em desenvolvimento no tocante às alegações do desequilíbrio existente no sistema de negociação

50 GUPTA, Surupa. A ausência de unidade entre os países em desenvolvimento: a ruína de Bali? 2013. Disponível em: <http:// www.ictsd.org/bridges-news/pontes/news/a-aus $\%$ C $3 \%$ AAnciade-unidade-entre-os-pa $\%$ C $3 \%$ ADses-em-desenvolvimento-aru\%C3\%ADna-de-bali>. Acesso em: 16 out. 2014.

51 HOEKMAN, Bernard M.; MAVROIDIS, Petros C. The World Trade Organization: law, economics, and politics. Abingdon: Routledge, 2007, p. 98. "(1) extending multilateral cooperation to domestic "behind the border" policies; (2) addressing concerns of developing countries that the trading system is "unbalanced"; and (3) dealing with the proliferation of preferential trade agreements. None of these challenges are new." multilateral e, por fim, precisam ainda lidar com a proliferação de acordos preferenciais de comércio, conforme já se mencionou anteriormente.

\section{0 órgão solucionador de controvérsias: conceituação e alcance}

Demonstradas, em síntese, as conquistas da OMC ao longo dos seus vinte anos de existência, bem como os problemas que enfrenta e os desafios a serem encarados no futuro pela organização, a partir desse momento serão tecidas considerações acerca de um dos seus mais importantes avanços dentro do sistema de comércio multilateral — o sistema de solução de controvérsias (OSC) - bem como serão abordados os principais aspectos do relacionamento do Brasil com a OMC, notadamente nas questões dirimidas pelo OSC.

O papel do Brasil, nesses últimos anos, numa postura que retrata sua intenção em encarar os desafios que lhe são propostos no cenário internacional vem intensificando a sua atuação diplomática frente às crises financeiras internacionais e seus reflexos no comércio. Por isso, especialmente desde a Rodada Doha, observase um aumento considerável do número de contenciosos comerciais, em especial no âmbito da Organização Mundial do Comércio (OMC). Hoje, como nunca antes, a atuação do Brasil no âmbito do mecanismo de solução de controvérsias da OMC tem permitido que o País não apenas defenda seus interesses comerciais, mas também contribua para a elaboração de normas justas de comércio multilateral.

Conforme já ressaltado, o mecanismo de solução de controvérsias (ou conflitos) é considerado o grande avanço da OMC, por estabelecer inovações entre as relações mantidas pelos Estados pertencentes a esta entidade. Esse órgão é composto por grupos que avaliam as reclamações dos Estados-membros e se propõe a solucionar as divergências havidas. Nesse avanço também está incluso o Órgão de Apelação, que pode ser concebido como uma "segunda instância" ou o "duplo grau de jurisdição" e que tem como objetivo principal garantir "uma solução positiva e pacífica para as controvérsias". ${ }^{52}$

Esse sistema consolidou uma visão mais legalista ${ }^{53}$ que o seu antecessor, o antigo GATT, mantendo

52 MELLO, Celso de Albuquerque. Curso de direito internacional público. Rio de Janeiro: Renovar, 2004, v. 2. p. 329.

53 CRETELLA NETO, José. Direito processual na Organização Mundial do Comércio. Rio de Janeiro: Forense, 2003, p. 61-62. 
ainda algumas regras anteriores, como as soluções negociadas diretamente entre os membros de forma diplomática. Havia ainda um único artigo sobre a solução de controvérsias (Artigo XXIII), que previa a possibilidade de investigação, recomendações ou determinações pelas partes contratantes, que poderiam suspender concessões negociadas entre as mesmas, se as circunstâncias fossem sérias o bastante para justificar tais medidas. A partir da criação do OSC salienta Seitenfus ${ }^{54}$ :

Para a OMC, os países membros que se encontrarem insatisfeitos devem se manifestar por meio do seu Órgão de Solução de Controvérsias (OSC) que irá analisar a existência de medidas restritivas ao comércio. Quanto a esse Sistema, no tocante às questões ambientais, convém ressaltar que o mesmo dá condições de os países membros utilizarem as regulamentações da própria organização para questionar as legislações ambientais nacionais ou regionais, o que pode trazer sérios prejuízos e controvérsias nas relações internacionais. Isso se deve ao fato de que "[...] seu sistema de solução de controvérsias quasejurisdicional [...] detém poder de sanção. O resultado é que se pode dotar de coercibilidade acordos que resultam de uma só abordagem: a do livre comércio.

Conforme já mencionado, a OMC também recebe críticas à medida que parece não se inteirar e encarar da maneira devida o chamado processo de "globalização" ou "mundialização", ou pior, só preocupar-se em analisar esse fenômeno do ponto de vista econômico comercial, desfazendo-se de outros importantes interesses transfronteiriços como a saúde e o meio ambiente.

Apesar disso o número de transações comerciais só vem crescendo e, como consequência, as controvérsias que são levadas à OMC. Desde a entrada em vigor do Entendimento Relativo às Normas e Procedimentos sobre Solução de Controvérsias da Organização Mundial do Comércio (OMC) $)^{55}$, em 1995, o Brasil tomou parte, como demandante ou demandado, em 41 dos 482 contenciosos iniciados na OMC até outubro

54 SEITENFUS, Ricardo Antônio Silva. Manual das organizações internacionais. 3. ed. Porto Alegre: Livraria do Advogado, 2003, p. 184.

55 Internalizado ao direito brasileiro por meio do Decreto $\mathrm{n}$. 1355/1994. de 2014 ${ }^{56}$, atrás apenas de Estados Unidos, União Europeia (UE), Canadá, China e Índia ${ }^{57}$.

Um outro aspecto positivo dessa participação brasileira está no fato de que o setor privado habilitouse, assim, a acompanhar as modificações que ocorreram na estrutura governamental e a interagir com o governo para a defesa de seus interesses na OMC. Os ministérios mais diretamente envolvidos no comércio internacional adequaram suas estruturas, capacitaram recursos humanos e aprimoraram a coordenação interministerial e com o setor privado, em particular após a criação da Câmara de Comércio Exterior (CAMEX) em 1995.

Em relação ao procedimento no âmbito do sistema de solução de controvérsias (OSC) se apontam as seguintes etapas de acordo com Entendimento Relativo às Normas e Procedimentos sobre Solução de Controvérsias ${ }^{58}$ :

Consulta: Cada Membro se compromete a examinar com compreensão a argumentação apresentada por outro membro e a conceder oportunidade adequada para consulta com relação a medidas adotadas dentro de seu território que afetem o funcionamento de qualquer acordo abrangido.

Painel (Grupos Especiais): É a primeira instância no procedimento para solução de controvérsias na OMC. São compostos por três indivíduos, que apresentam o relatório circunstanciado sobre a controvérsia e uma análise jurídica quanto ao fundamento da reclamação. Tem como competência: examinar a questão submetida e estabelecer conclusões que auxiliem o OSC a fazer recomendações ou emitir decisões. Antes de emitir uma decisão (relatório), o painel apresenta

56 WORLD TRADE ORGANIZATION. Brasil and the WTO. Disponível em: <http://www.wto.org/english/thewto_e/ countries_e/brazil_e.htm\#disputes>. Acesso em: 16 out. 2014.

57 A título de comparação e a fim de demonstrar o alto interesse dos Estados-membros por esse órgão em seus 20 anos de existência, vale ressaltar que, na Corte Internacional de Justiça, em seus 67 anos, são 153 casos demandados, e no Tribunal de Direito do Mar, estabelecido um após o OSC, apenas 21. Portanto, o órgão da OMC, sem dúvida, tem logrado êxito em sua atuação.

58 BRASIL. Ministério das Relações Exteriores. Entendimento Relativo às Normas e Procedimentos sobre Solução de Controvérsias (ESC). Disponível em:

$<$ http://www.itamaraty.gov.br/o-ministerio/conhecao-ministerio/tecnologicos/cgc/solucao-de-controversias/maisinformacoes/texto-dos-acordos-da-omc-portugues/2-anexo-2entendimento-relativo-as-normas-e-procedimentos-sobre-solucaode-controversias/view>. Acesso em: 16 out. 2014. 
um esboço descritivo, e um relatório provisório, ainda confidencial, que poderá ser objeto de comentários pelas partes na controvérsia. Após essa fase, o relatório do painel circula entre todos os Membros da OMC e é colocado à disposição no sítio eletrônico. Submetido o relatório ao OSC, será ele aprovado, a não ser que haja consenso reverso ou que uma das partes da controvérsia recorra ao OAp (Órgão Permanente de Apelação), o que geralmente ocorre.

Apelação: Diante da OAp, as partes apresentam seus argumentos escritos e em audiência. As deliberações dos juízes do OAp são confidenciais, e o relatório final aprovado, confirmando, modificando ou revogando o relatório do painel; é então remetido ao OSC, onde será aprovado. Com a aprovação pelo OSC do relatório do painel ou do OAp, encerra-se a fase jurisdicional do sistema de solução de controvérsias da OMC.

No relatório final aprovado, se concluir que a medida nacional reclamada é incompatível com os acordos da OMC, deverá recomendar que o membro torne a medida compatível com o acordo.

O Entendimento Relativo a Normas e Procedimentos sobre Solução de Controvérsias (ESC), Anexo 02, do Acordo Constitutivo da Organização Mundial do Comércio, é o resultado de uma longa evolução da solução de controvérsias no âmbito do Acordo Geral sobre Tarifas Aduaneiras e Comércio de 1947. Esse procedimento, que deixou de vigorar em 31 de dezembro de 1995, teve seus princípios preservados no novo procedimento, objeto do Anexo 02 do Acordo da OMC. Seu objetivo é o de manter a imparcialidade de julgamentos, garantindo uma previsibilidade legal dos julgamentos e facilitando o comércio internacional.

O êxito do órgão se deve, além da qualidade de seus julgados, à relativa rapidez das decisões proferidas. Há prazo de sessenta dias para a realização das consultas (Artigo 4.7 do Entendimento de Solução de Controvérsias (ESC), seis meses para a decisão do painel (Artigo 12.8 do ESC) e noventa dias para o Órgão de Apelação (OA) (Artigo 17.5 do ESC)). Prazos mais curtos podem, inclusive, ser estabelecidos, em casos excepcionais, conforme especificado nos Acordos pertinentes da OMC. Em média, um contencioso não deveria levar mais de dois anos entre o pedido de consultas e a adoção das recomendações pelo OSC, após recurso ao Órgão de Apelação; embora na prática existam casos que levaram mais tempo para serem solucionados.

Além das etapas acima definidas, outro ponto que influenciou substancialmente a estrutura do sistema de modo positivo foi o novo princípio do "consenso negativo". Agora, por esse princípio, para um painel seja bloqueado, é necessária a vontade de todos os Membros, inclusive do demandante, o que faz com que o novo procedimento seja quase automático, acarretando maior seriedade ao tema.

E mais, O ESC prevê uma pluralidade de procedimentos para solucionar as controvérsias no âmbito da OMC. Além do procedimento "central", desenvolvido pelo Grupo Especial (Painel) e pelo Órgão de Apelação, também não excluem-se os chamados, "procedimentos alternativos", que são os "bons ofícios", a "conciliação", a "mediação" e a "arbitragem".

\section{As soluções de controvérsias na OMC e o Brasil: efetivação do comércio e desenvolvimento de uma política econômico-diplomática}

Nas últimas décadas, o Brasil tem apresentado crescente participação em blocos econômicos, consequência de seu crescimento e diversidade comercial. Assim como outros países, apesar do aumento no volume de transações comerciais, o país encara também na OMC a difícil e problemática conceituação de "país em desenvolvimento" e seus efeitos.

Nessa seara, o processo de abertura e de desburocratização pelo qual tem passado a OMC nos últimos anos, tem favorecido países como o Brasil, especialmente, com a reformulação das formas de solução de conflito. Nesse sentido, o OSC atual permite uma participação mais justa e vantajosa ao comércio brasileiro.

O tratamento diferenciado/especial dado aos países em desenvolvimento desde a Rodada do Uruguai pode ser classificado em cinco grupos $^{59}: 1$ ) disposições destinadas a aumentar as oportunidades

59 YOSHIURA, Jackson Apolinário. Os países em desenvolvimento no sistema de solução de controvérsias da OMC. Boletim de Ciências Económicas, Coimbra, v. 53, 2010, p. 95-181, p. 117. Disponível em: $<$ https://digitalisdsp.uc.pt/bitstream/10316.2/24714/1/BoletimLIII_Artigo4.pdf>. Acesso em: 16 out. 2014. 
comerciais; 2) salvaguarda dos interesses dos países em desenvolvimento; 3) maior flexibilidade para os países em desenvolvimento nas normas do GATT; 4) período mais longo de transição para a adoção das obrigações provenientes das negociações; e 5) assistência técnica relacionada com o comércio.

A legislação brasileira mantém certa coerência com as regras multilaterais e faz com que os acordos da OMC tenham força de lei no ordenamento jurídico interno, isso reduz as vulnerabilidades no sistema de solução de controvérsias e se reflete no baixo número de controvérsias contra o Brasil que resultaram em necessidade de modificação, de alguma forma, da legislação brasileira. Para continuar esse processo, faz-se necessário que os formuladores de medidas de impacto na política comercial estejam conscientes das obrigações internacionais do Brasil, a fim de manter uma perspectiva positiva do país diante das formas de solução de controvérsias propostas pela OMC. Diante disso, pode-se afirmar que existe sempre uma necessidade de adequação dos Estados-membros. Sobre isso afirma Lafer $^{60}$ :

60 LAFER, Celso. A OMC e a regulamentação do comércio internacional:
O mercado e a concorrência podem ser vistos como uma grociana luta de todos em prol de todos. Essa é a tese do doux commerce. Simmel observou que o mercado e a concorrência são, no entanto, simultaneamente uma hobbesiana guerra de todos contra todos [...]. Para evitar a confrontação bélica de uma concorrência desenfreada baseada no poder, a administração do conflito e da cooperação no mercado requer um enquadramento jurídico. A OMC prevê esse enquadramento através de um ordenamento jurídico, o single undertaking, concebido como um jogo de normas de fair play compartilhadas por todos os membros [...] O sistema de solução de controvérsias da OMC representa não só codificação, mas um desenvolvimento progressivo do direito e da prática do GATT.

Os casos que envolveram o Brasil no OSC podem ser descritos no quadro abaixo:

\section{Quadro 1 - Casos de disputa envolvendo o Brasil ${ }^{61}$}

uma visão brasileira. Porto Alegre: Livraria do Advogado, 1998, p. 9. 61 WORLD TRADE ORGANIZATION. Disputing cases envolving

\begin{tabular}{|c|c|c|}
\hline DEMANDANTE & DEMANDADO & TERCEIRA PARTE \\
\hline 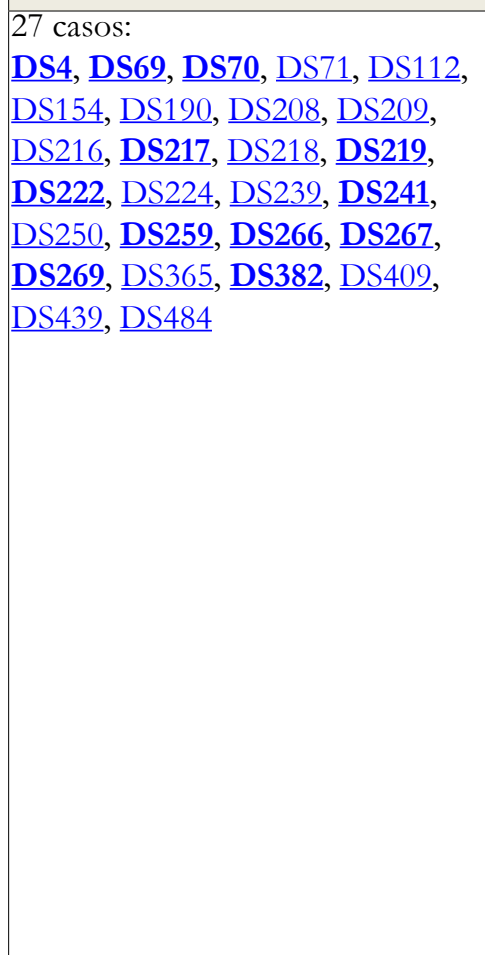 & 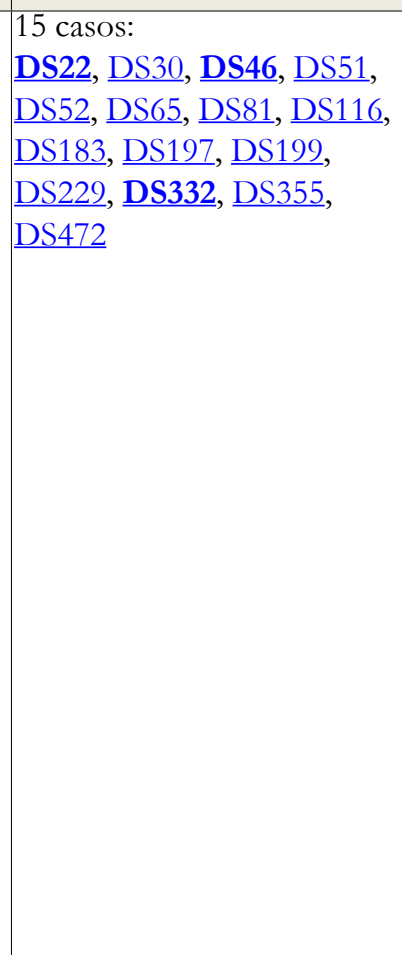 & 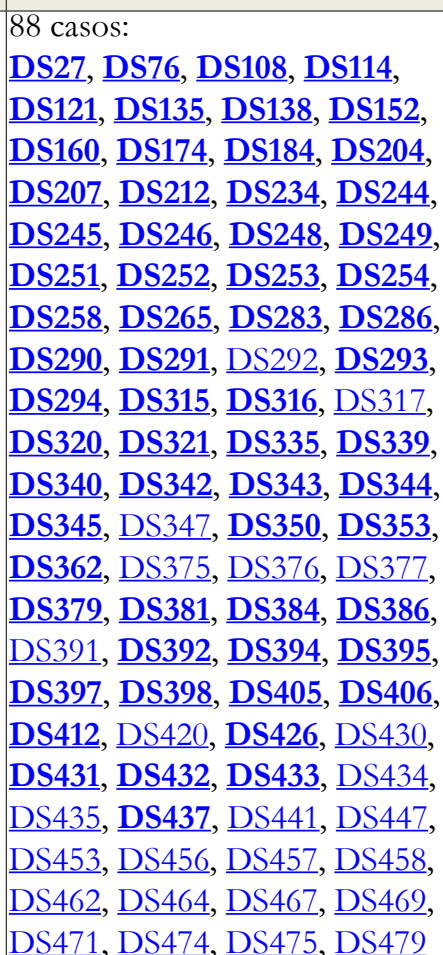 \\
\hline
\end{tabular}

Fonte: http://www.wto.org/english/thewto_e/countries_e/brazil_e.htm\#disputes 
Diante do grande número de casos, faz-se importante ressaltar os que revelam a estrutura e atividade do OSC e a atuação brasileira, cada vez mais especializada, ultrapassando seu caráter contencioso e criando novas páginas da política externa.

A atuação brasileira ocorreu especialmente em contenciosos que envolvem setores exportadores brasileiros dinâmicos, como o aeronáutico (Embraer vesus Bombardier); o siderúrgico (Emenda Byrd e salvaguardas americanas sobre certos produtos siderúrgicos); o de algodão (subsídios americanos à cotonicultura); o de açúcar (subsídios à exportação concedidos pela UE); o de frango salgado (reclassificação tarifária feita pela UE); o de suco de laranja (taxa de equalização americana); e o de bananas (arbitragem sobre regime de tarifa única europeu), dentre outros.

Também é importante ressaltar que a maneira de cada Estado-membro executar internamente uma decisão emanada do OSC pode variar. Os efeitos e alcance dessas decisões no ordenamento jurídico interno dos diferentes membros podem variar consideravelmente de acordo com a estrutura constitucional e o ordenamento jurídico de cada um deles, a quem cabe, em última instância, determinar sua hierarquia em relação ao direito interno e se esses atos podem ser arguidos em tribunais nacionais. No Brasil se pode vislumbrar o seguinte ${ }^{62}$ :

A situação no Brasil não difere muito. A Constituição Federal (CF) não contém nenhum dispositivo explícito sobre a interação dos atos emanados das OI com o ordenamento jurídico brasileiro. $\mathrm{O}$ texto constitucional limita-se a estabelecer, em seu artigo $4^{\circ}$ inciso IX, que o Brasil deverá balizar-se, nas suas relações internacionais, pela "busca da cooperação entre os povos", atribuindo à União, no artigo 21, a competência de "manter relações com Estados estrangeiros e participar de organizações internacionais". Não há, no entanto, na Constituição, nenhuma previsão específica sobre o alcance dos atos emanados dessas organizações, que tampouco figuram no rol de instrumentos legislativos estabelecidos no artigo 59 da CF. Tampouco há, no direito positivo brasileiro, elementos que permitam inferir de

62 BENJAMIM, Daniela Arruda. A aplicação interna das decisões do Órgão de Solução de Controvérsias da OMC na prática. In: BENJAMIM, Daniela Arruda (Org.). O Sistema de Solução de Controversias da OMC: uma perspectiva brasileira. Brasília: Fundação Alexandre de Gusmão, 2013. p. 586-587. forma inequívoca como, na prática, a integração desses atos no direito interno deveria se operar.

Por isso, cada Estado acabou por imprimir uma forma própria de implementação das decisões no que tange à receptação dessas normas em seu ordenamento. Resta claro que nosso país está apto a aplicar, no julgamento dos casos submetidos a sua apreciação, normas internacionais adotadas pelo Brasil. Nesse sentido, interessante o julgamento do STJ, no âmbito do Recurso Extraordinário n. 821-406, de 2007, que aplicou as Súmulas 20 e 71 do STJ e a Súmula 575 do STF, afirmando ser:

pacífica é a jurisprudência do STJ no sentido de que a mercadoria importada de país signatário do GATT é isenta de ICMS, quando contemplado com esse favor o similar nacional, em aplicação do princípio do tratamento nacional consagrado nos acordos da OMC. ${ }^{63}$

Portanto, é inegável que uma vez internalizada a Ata Final que aprova os Resultados da Rodada Uruguai de Negociações Comerciais (Decreto n. 1355/94), que estabeleceu a OMC, o Brasil conferiu aos acordos da OMC hierarquia de lei interna e estabeleceu, entre outras coisas, a obrigação de "garantir a conformidade de suas leis, regulamentos e procedimentos com os Acordos da OMC." ${ }^{4}$

\subsection{O Brasil nos Contenciosos da OMC: Aspectos Relevantes}

É importante apontar alguns elementos que marcaram a atuação brasileira ${ }^{65}$ nos contenciosos da OMC. Dado o volume de casos, salientam-se alguns que foram determinantes para condução da política externa brasileira junto ao comércio internacional.

63 BENJAMIM, Daniela Arruda. A aplicação interna das decisões do Órgão de Solução de Controvérsias da OMC na prática. In: BENJAMIM, Daniela Arruda (Org.). O Sistema de Solução de Controversias da OMC: uma perspectiva brasileira. Brasília: Fundação Alexandre de Gusmão, 2013. p. 589.

64 BENJAMIM, Daniela Arruda. A aplicação interna das decisões do Órgão de Solução de Controvérsias da OMC na prática. In: BENJAMIM, Daniela Arruda (Org.). O Sistema de Solução de Controvérsias da OMC: uma perspectiva brasileira. Brasília: Fundação Alexandre de Gusmão, 2013. p. 591.

65 Já em 1995, o país figurava como demandante, ao lado da Venezuela, em um dos primeiros contenciosos da OMC (caso USGasoline), 3 em que medidas ambientais foram avaliadas segundo as disciplinas multilaterais de comércio. 
Dentre os casos em que o Brasil foi demandante, podese citar: ${ }^{66}$

- DS 222 - Canadá - Créditos e garantias à indústria aeronáutica - "Embraer-Bombardier" (DS46/DS70/ DS222);

- DS 266 - Comunidades Europeias - Subsídios à Exportação de Açúcar (Brasil);

- DS 267 - Estados Unidos - Subsídios ao Algodão (Brasil);

- DS 269 - Comunidades Europeias - Classificação Aduaneira do Frango Desossado Congelado (Brasil);

\section{- $\quad$ DS 382 - Estados Unidos - Medidas Antidumping} sobre Suco de Laranja (Brasil).

A sucinta análise de alguns deles permite verificar como tem sido a atuação do Brasil junto ao OSC da OMC.

Um dos casos emblemáticos do Brasil junto ao OSC ficou conhecido como "Embraer-Bombardier" (DS46/ DS70/DS222) e se destacou pela discussão quanto ao uso de subsídios dos governos junto às empresas do setor aeronáutico (Acordo sobre Subsídios e Medidas Compensatórias - ASMC). A disputa iniciou-se em 1996 e colocava o Canadá contra o Brasil na discussão acerca das políticas usadas para comércio de aviões em dois processos paralelos a partir de 1998 (DS46 e DS70).

O Canadá questionava o programa "PROEX Equalização", considerado pela OMC como um programa de subsídios proibidos em sua versão original, enquanto o Brasil acentuava a ilegalidade de vários programas de subsídios (Export Development Canada e Technology Partnerships Canada).

Dentre suas principais decisões o OSC determinou que os parâmetros para concessão de créditos à exportação definidos no âmbito da Organização para a Cooperação e o Desenvolvimento Econômico (OCDE), organização internacional da qual o Brasil não é parte, eram aplicáveis a todos os membros da OMC, por

66 BRASIL. Ministério das Relações Exteriores. Brasil como demandante. Disponível em: $<$ http://www.itamaraty.gov.br/oministerio/conheca-o-ministerio/tecnologicos/cgc/solucaode-controversias/participacao-do-brasil-nos-contenciososdocumentos/brasil-como-demandante>. Acesso em: 18 out. 2014. força do segundo parágrafo da alínea "k" do Acordo sobre Subsídios e Medidas Compensatórias (ASMC). Com isso o Canadá recebeu o direito de retaliação ao Brasil em C\$344,2 milhões/ano. Apesar dessa primeira derrota, o caso provocou uma reviravolta na política externa do Brasil que soube aproveitar e implementar as mesmas medidas a seu favor posteriormente.

Assim, no DS 222, o Brasil foi autorizado a retaliar o Canadá em mais de US $\$ 247$ milhões, ao confirmar que programas federais e provinciais (Québec) canadenses subsidiaram fortemente operações de vendas da Bombardier em 2001, comprovando que o subsídio dado a cada avião no Canadá superava muito o adotado pelo Brasil. A fim de evitar maiores prejuízos, em 2007 foi aprovado um novo "Acordo Setorial sobre Créditos à Exportação para Aeronaves Civis", estruturado com grande participação do nosso governo. Assim pode ser resumido o quadro desse caso:

\section{Quadro 2-Resumo de disputa por data}

\begin{tabular}{|l|l|}
\hline Título: & $\begin{array}{l}\text { Canada - Aircraft Credits } \\
\text { and Guarantees }\end{array}$ \\
\hline Demandante: & Casil \\
\hline Demandado: & $\begin{array}{l}\text { Australia; European } \\
\text { Communities; India; United } \\
\text { States }\end{array}$ \\
\hline Terceiras partes: & $\begin{array}{l}\text { Subsidies and Countervailing } \\
\text { Measures: Art. } 1, \underline{3}\end{array}$ \\
\hline Acordos citados: & 22 Jan. 2001 \\
\hline Data de requerimento da \\
consulta:
\end{tabular}

Fonte: http://www.wto.org/english/tratop_e/ dispu_e/cases_e/ds222_e.htm

O próximo caso do qual o Brasil extraiu grande experiência ficou conhecido como "disputa do açúcar". Acerca dos subsídios europeus a esse produto, foi iniciado em 27/09/2002, com base no pedido de consultas formulado por Brasil (DS266) e Austrália (DS265). Em março de 2003, a Tailândia (DS283) apresentou pedido de consultas sobre o mesmo objeto, razão pela qual os três Estados-membros da OMC figuraram como codemandantes contra a Comunidade Europeia (CE) em painel uno para julgar esses contenciosos.

67 WORLD TRADE ORGANIZATION. Dispute settlement: Dispute ds222. Disponível em: <http://www.wto.org/english/ tratop_e/dispu_e/cases_e/ds222_e.htm>. Acesso em: 19 out. 2014 
O Brasil questionou na $\mathrm{OMC}$ o fato de que as exportações anuais subsidiadas de açúcar pela CE ultrapassavam os compromissos assumidos pelo bloco europeu perante aquela organização (já que a CE não computava nas vendas uma espécie de açúcar chamada de "açúcar C", driblando assim sua fiscalização). O Brasil conseguiu comprovar que a $\mathrm{CE}$ se beneficiava de subsídios cruzados, i.e., subsídios concedidos à produção do açúcar das quotas "A" e "B", os quais "transbordavam" para a produção do "açúcar C" (spillover effect). Mais uma vez o Brasil e demais demandantes venceram a questão. A CE foi obrigada a reformar seu regime açucareiro, o que de fato ocorreu em 1/7/2006, quando uma nova Organização Comum de Mercado (OCM) para o açúcar foi introduzida pelo Regulamento n. 318/2006.

Diante disso os europeus não somente deixaram de depreciar o produto provindo de outros Estados, como também tiveram que recalcular seus preços sem os subsídios, tornando o mercado mais competitivo, o que já proporcionou ao Brasil o dobro de exportações no ano seguinte à contenda. Sobre esse caso é possível apresentar o seguinte quadro:

\section{Quadro 3 - Resumo de disputa por data ${ }^{68}$}

\begin{tabular}{|c|c|}
\hline Título: & EC - Export Subsidies on Sugar \\
\hline Demandante: & Brasil \\
\hline Demandado: & European Communities \\
\hline Terceiras partes: & $\begin{array}{l}\text { Australia; Barbados; Belize; Canada; } \\
\text { China; Colombia; Cuba; Fiji; Guyana; } \\
\text { India; Jamaica; Kenya; Madagascar; } \\
\text { Malawi; Mauritius; New Zealand; } \\
\text { Paraguay; Saint Kitts and Nevis; } \\
\text { Swaziland; Tanzania; Thailand; } \\
\text { Trinidad and Tobago; United States; } \\
\text { Côte d'Ivoire }\end{array}$ \\
\hline Acordos citados: & $\begin{array}{l}\text { Agriculture: Art. } \underline{3.3}, \underline{8}, \underline{9.1}, \underline{10.1} \\
\text { GATT 1994: Art. } \underline{\mathrm{II}}: \underline{4}, \underline{\mathrm{XVI}} \\
\text { Subsidies and Countervailing } \\
\text { Measures: Art. } 1.1, \underline{3.1}, \underline{3.2}\end{array}$ \\
\hline $\begin{array}{l}\text { Data de } \\
\text { requerimento da } \\
\text { consulta: }\end{array}$ & 27 Sept. 2002 \\
\hline Data do Painel: & 15 Oct. 2004 \\
\hline Data da apelação: & 28 April 2005 \\
\hline $\begin{array}{l}\text { Relatório de } \\
\text { arbitragem (Artigo } \\
21.3 \text { c): }\end{array}$ & 28 Oct. 2005 \\
\hline
\end{tabular}

Fonte: https://www.wto.org/english/tratop_e/ dispu_e/cases_e/ds266_e.htm

O próximo caso constitui a pedra de toque das disputas e discussões havidas no âmbito da OMC. Diz respeito a um problema crucial enfrentado pelos países

68 WORLD TRADE ORGANIZATION.. Dispute settlement: Dispute ds266. Disponível em: < <ttps://www. wto.org/english/tratop_e/dispu_e/cases_e/ds266_e.htm>. Acesso em: 19 out. 2014 em desenvolvimento: os subsídios utilizados pelos países desenvolvidos na agricultura. Isso fez com que ao mesmo tempo em que se propusesse o caso do açúcar junto ao OSC, se fizesse o mesmo relativamente aos casos da agricultura, notadamente no caso do algodão.

Foi possível, por esse painel, analisar que, de 19992002, os EUA tinham concedido US $\$ 12,9$ bilhões em subsídios, o que equivalia a uma taxa de subsidiamento à produção de $89,5 \%$, em média. Dessa forma, sem essa arma, o algodão americano seria aproximadamente $9 \%$ mais caro. Foi o caso mais complexo enfrentado pelo Brasil e pela OMC até então, esgotando todos os procedimentos previstos no OSC: consultas, painel, apelação, painel de implementação (Artigo 21.5 do ESC), nova apelação e painel de retaliação (Artigo 22.6 do ESC).

O fundamental da análise desse caso está nas medidas comerciais tomadas pelo Brasil a partir dessa experiência contenciosa. Como exemplo, a implementação da política de retaliação ${ }^{69}$, autorizada pela OMC no caso do algodão americano, que culminou na Resolução no 15/2010 da CAMEX, com lista final contendo 102 bens sobre os quais incidiria a retaliação. Ainda sobre os efeitos desse caso, inclui-se a retaliação cruzada:

Em paralelo aos trabalhos na retaliação em bens, foram sendo delineadas as possíveis medidas a serem adotadas no campo da retaliação cruzada. [...] Antes de tudo, era necessário conferir o devido amparo legal à retaliação cruzada, particularmente no que tange à suspensão de direitos de propriedade intelectual. Para tanto, a CAMEX determinara, em agosto de 2007 — muito antes da instauração do procedimento de arbitragem da retaliação no contencioso do algodão, portanto o estabelecimento de subgrupo dentro do Grupo Interministerial de Propriedade Intelectual (GIPI) com vistas à revisão do arcabouço normativo existente e elaboração de uma proposta de legislação. $O$ trabalho culminou na edição da Medida Provisória 48213, que atribui à CAMEX competência para suspender diversos direitos de

69 Até então há um total de 8 casos que envolviam a temática da retaliação (incluindo o caso do algodão), num total de mais de 400 casos iniciados até hoje. Casos em que houve retaliação efetiva: 5. Membros da OMC que já retaliaram: EUA, EU, Canadá e Japão. Membros que foram autorizados, mas não retaliaram: Brasil (em 2 casos: Canada Aircraft e Byrd Amendment), Chile, Índia, Coréia, México, Equador e Antigua. 
propriedade intelectual conforme necessário para implementar uma retaliação cruzada. ${ }^{70}$

Esse processo de retaliação é a exceção que confirma a prioridade conferida pelo Brasil à proteção da propriedade intelectual. Como resultado, em junho de 2010, assinou-se um Acordo Quadro entre os dois países, solução momentânea que previu o pagamento da maior compensação financeira da história da OMC. Eis o quadro:

\section{Quadro 4 - Resumo de disputa por data ${ }^{7}$}

\begin{tabular}{|c|c|}
\hline Título: & US - Upland Cotton \\
\hline Demandante: & Brasil \\
\hline Demandado: & United States \\
\hline Terceiras Partes: & $\begin{array}{l}\text { Argentina; Australia; Benin; } \\
\text { Canada; Chad; China; Chinese } \\
\text { Taipei; European Communities; } \\
\text { India; New Zealand; Pakistan; } \\
\text { Paraguay; Venezuela, Bolivarian } \\
\text { Republic of; Japan; Thailand }\end{array}$ \\
\hline Acordos citados: & $\begin{array}{l}\text { Agriculture: Art. } \underline{3.3}, \underline{7.1}, \underline{8}, \underline{9.1} \text {, } \\
10.1 \\
\text { GATT 1994: Art. } \underline{\mathrm{III}}: 4, \underline{\mathrm{XVI}} \\
\text { Subsidies and Countervailing } \\
\text { Measures: Art. } \underline{3}, \underline{5}, \underline{6}\end{array}$ \\
\hline $\begin{array}{l}\text { Data do requerimento da } \\
\text { consulta: }\end{array}$ & 27 Sep. 2002 \\
\hline Data do painel: & 8 Sep. 2004 \\
\hline Data da apelação: & 3 March 2005 \\
\hline $\begin{array}{l}\text { Relatório do painel (Art. } \\
\text { 21.5): }\end{array}$ & 18 Dec. 2007 \\
\hline $\begin{array}{l}\text { Relatório da apelação } \\
\text { Art. 21.5: }\end{array}$ & 2 June 2008 \\
\hline $\begin{array}{l}\text { Relatório da arbitragem } \\
\text { (Art. 22.6): }\end{array}$ & 31 Aug. 2009 \\
\hline
\end{tabular}

Fonte: http://www.wto.org/english/tratop_e/ dispu_e/cases_e/ds267_e.htm

Após a experiência acumulada em alguns dos primeiros casos na OMC (Coco Ralado, Gasolina, Frangos e Aeronaves), a complexidade crescente dos assuntos discutidos nos painéis levou à melhor estruturação da participação brasileira, que, com o tempo, passou a basear-se nos seguintes quesitos: (i) Coordenação-Geral de Contenciosos no MRE (área criada em 10/10/2001); (ii) Delegação do Brasil em Genebra; e (iii) apoio, quando necessário, de escritório

70 SCHMIDT, Luiz Fellipe Flores. A construção da retaliação brasileira no caso do algodão: os desafios do pioneirismo. In: BENJAMIM, Daniela Arruda (Org.). O Sistema de Solução de Controvérsias da OMC: Uma perspectiva brasileira. Brasília: Fundação Alexandre de Gusmão, 2013, p.641

71 WORLD TRADE ORGANIZATION. Dispute settlement: Dispute ds267. Disponível em: <http://www.wto.org/english/ tratop_e/dispu_e/cases_e/ds267_e.htm>. Acesso em: 19 out. 2014 de advocacia especializado, além de interação constante com o setor privado.

Dessa forma o Brasil lutou pela inaplicabilidade de medidas que desfavorecem a concorrência entre os países e que implicam deliberadamente na política de proteção da indústria nacional, aplicada por vários Estados-membros e até mesmo na conceituação e aplicação de dumping (e de antidumping) pelos diferentes membros, como ocorreu no caso do frango (2003), dos pneus reformados (2005) e do suco de laranja (2008).

A atual temática do OSC vem contemplando novos temas como sustentabilidade ambiental, fontes renováveis de energia e exploração de recursos naturais, o que interessa sobremaneira ao Brasil, portanto, somente o acompanhamento de perto dessas questões e do seu deslinde poderá propiciar novas explanações e o delineamento dos novos contornos da atividade do OSC e da participação do Brasil nesse contexto.

\section{Considerações finais}

A OMC é uma das instituições multilaterais mais bem-sucedidas do período pós-1945. Apesar da ausência de uma autoridade central, a cooperação entre os seus Estados-membros tem sido sustentada por mais de 50 anos, apesar de suas imperfeições e lacunas, conforme se demonstrou no decorrer do presente trabalho. Apesar de todos os desafios que foram apresentados ao longo deste escrito, pode-se afirmar que o grau de comprometimento de seus membros para com a OMC é bastante alto, não havendo até o presente momento notícias de países considerem deixá-la.

Com um sistema de regras substancialmente mais desenvolvido e sofisticado do que aquele previsto no seu antecessor (GATT), a OMC conseguiu alcançar algumas conquistas importantes desde a sua criação, tais como o estabelecimento de uma base jurídica sólida para o sistema de comércio internacional multilateral; a projeção como único fórum onde são definidas as regras para o comércio internacional em escala mundial, propiciando maior segurança jurídica, estabilidade e previsibilidade para as relações comerciais multilaterais internacionais; a inserção de diferentes Estados no mercado internacional, inclusive trazendo para o âmbito da organização parceiros de peso; o estabelecimento de um sistema de solução de controvérsias dos mais avançados no mundo; em certa medida, a limitação do protecionismo dos países em 
relação aos seus mercados internos; e a conclusão de um primeiro acordo comercial em escala global.

No entanto, o lado negro da história também foi demonstrado no decorrer do texto, em que restaram evidenciados os maiores desafios que a organização terá que enfrentar nos próximos anos, consistentes na retomada efetiva das negociações da Rodada de Doha; na adequação de sua estrutura e normativa para tentar incluir os acordos regionais e bilaterais e suas regras; e na necessidade de uma reforma na governança da instituição. Certamente, para que a OMC possa recobrar fôlego e credibilidade como organismo internacional de gestão eficiente das relações comerciais internacionais multilaterais, os desafios apresentados ao logo do texto terão que ser superados.

Também se verificou a necessidade de uma atuação mais eficaz da OMC para que possa atender à dinâmica das relações internacionais hodiernas, que são complexas e desafiantes ao sistema inicialmente concebido pela organização. Para oferecer respostas rápidas e eficazes aos problemas que se apresentam, conforme visto, examinou-se a necessidade de uma reestruturação organizacional da instituição, bem como um repensar e um remodelar de alguns de seus institutos fundamentais, tais como a regra do consenso e o princípio do single undertaking.

Sem prejuízo de outras medidas e alternativas não vislumbradas no presente trabalho, sem que mudanças essenciais como as que aqui foram apontadas sejam tomadas, dificilmente a organização conseguirá sobreviver no cenário internacional, não como uma instituição proativa e eficiente na consecução dos resultados para os quais foi criada. A OMC não é uma obra acabada e concessões feitas pelos Estadosmembros a fim de torná-la um órgão que funcione serão essenciais.

Em relação ao sistema de solução de controvérsias, em cotejo com os casos em que o Brasil foi parte, diante dos contenciosos analisados e de outros tantos que já ocorreram e que estão por vir uma verdade é certa, o Brasil avançou e muito em suas negociações internacionais, passou a lutar por um posicionamento respeitável no comércio internacional e mais ainda, traçou caminhos dos quais não mais se distanciará.
Mais do que crescimento econômico o país alcançou uma maior maleabilidade na política externa que o possibilita trilhar novos mercados. Isso sem dúvida é o maior bem que se vislumbra após anos de criação do OSC da OMC.

Diante disso o quadro que se vê é extremamente positivo, principalmente se lembrarmos que as decisões precedentes estão servindo de modelo para outras e criando um condão fundamental para previsibilidade do comércio e confiabilidade junto à OMC. O Brasil ainda hoje é o país em desenvolvimento que mais acionou o mecanismo como parte demandante ou demandada, atuando em casos envolvendo setores estratégicos, mesmo quando o órgão de resolução se mantém ainda desafiador para países em desenvolvimento.

Por isso, há que se notar também a persistência de alguns pontos negativos no sistema de solução de controvérsias que ainda perecem à falta de melhoramento. São eles; a fragilidade ou dificuldade de defesa dos países em desenvolvimento; vez que para esses membros muitas vezes, a defesa junto ao órgão exige custos econômicos e de formação profissional elevados.

Outro aspecto que merece atenção é a alternância dos temas propostos ao logo dos anos. Se por um lado a dinâmica econômica exige constante adaptação dos países e da OMC, por outro, o surgimento de novas searas econômicas coloca todos em situação de despreparo, o que acarreta, na maioria das vezes, um atraso considerável para as decisões finais na OMC e o consequente aumento de custos para proposição das demandas junto ao OSC.

Resta a certeza de que tanto a OMC, como organização comercial, tanto seu órgão solucionador de controvérsias, OSC, encontram pela frente desafios que alternam com rapidez do mercado internacional e globalizado. A criação de fronteiras e limitações comerciais esbarra cada vez mais em valores que perpassam os interesses nacionais e vislumbram aspectos outrora fundamentais do jus gentium. Isso só demonstra que embora se crie novas fronteiras econômicas, a sociedade internacional cada vez mais se quedará a decisões que preferenciem a igualdade, a justiça e a manutenção dos bens e valores universais. 


\section{Referências}

ARAUJO, Leandro Rocha de; COSTA Valeria M.; PEREIRA, Celso de Tarso. 100 casos na OMC: a experiência brasileira em solução de controvérsias. Disponível em: $\quad<$ http://politicaexterna.com. br/384/100-casos-omc-experiencia-brasileira-solucaocontroversias/>. Acesso em: 16 out. 2014.

BARRAL, Welber (Org.). Tribunais Internacionais: mecanismos contemporâneos de solução de controvérsias. Florianópolis: Fundação Boiteux, 2004.

BENJAMIM, Daniela Arruda (Org.). O Sistema de Solução de Controvérsias da OMC: uma perspectiva brasileira. Brasília: Fundação Alexandre de Gusmão, 2013.

BRASIL. Ministério das Relações Exteriores. Entendimento Relativo às Normas e Procedimentos sobre Solução de Controvérsias (ESC). Disponível em: <http://www. itamaraty.gov.br/o-ministerio/conheca-o-ministerio/ tecnologicos/cgc/solucao-de-controversias/maisinformacoes/texto-dos-acordos-da-omc-portugues/2anexo-2-entendimento-relativo-as-normas-eprocedimentos-sobre-solucao-de-controversias/view>. Acesso em: 16 out. 2014.

BREVIGLIERI, Etiene M. B.; FIORATI, Jete Jane; RAUCCI, Regina Maciel. Direito do comércio internacional e meio ambiente: as exceções não comerciais e a OMC. Jaboticabal: FUNEP, 2010.

CAPARROZ, Roberto. Comércio internacional esquematizado. São Paulo: Saraiva, 2012.

COSTA, José Augusto Fontoura. Decidir e julgar: um estudo multidisciplinar sobre a solução de controvérsias na OMC. 2009. Tese (doutorado) - Departamento de Direito Internacional e Comparado, Faculdade de Direito, Universidade de São Paulo, São Paulo, 2009.

CRETELLA NETO, José. Direito processual na Organização Mundial do Comércio. Rio de Janeiro: Forense, 2003.

DÉNIZ, Pedro Talavera. La regulación del comercio internacional: del GATT a la OMC. Barcelona: Universitat de Barcelona, 1995.

EVENETT, Simon J. The Doha Round Impasse. Disponível em: <http://graduateinstitute.ch /files/live/sites/iheid/
files/shared/summer/WTO2012/protected/Evenett_ Doha_Round_Impasse_paper_March_2012\%20 revised.pdf>. Acesso em: 14 out. 2014.

HOEKMAN, Bernard M.; MAVROIDIS, Petros C. The World Trade Organization: law, economics, and politics. Abingdon: Routledge, 2007.

KEOHANE, Robert O. After hegemony: cooperation and discord in the world political economy. Princeton: Princeton University Press, 1984.

KLOR, Adriana Dreyzin de. et al. Solução de controvérsias: OMC, União Europeia e Mercosul. Rio de Janeiro: Konrad-Adenauer-Stiftung, 2004.

LAFER, Celso. A OMC e a regulamentação do comércio internacional: uma visão brasileira. Porto Alegre: Livraria do Advogado, 1998.

LANDIM, Raquel. É a bora de acabar com a utopia do consenso na OMC. Disponível em: <http://www1.folha. uol.com.br/colunas/raquellandim/2013/12/1382381e-a-hora-de-acabar-com-a-utopia-do-consenso-naomc.shtml>. Acesso em: 15 out. 2014.

LIMA, Maria Lúcia Labate Mantovanini Padua; ROSENBERG, Barbara (Coords.). O Brasil e o contencioso na OMC. São Paulo: Saraiva, 2009.

MACIEL, George Álvares. A dimensão multilateral: o papel do GATT na expansão da economia, a Rodada Uruguai e a criação da OMC em 1994. Boletim de Diplomacia Econômica, Brasília, n. 19, p. 130-146, 1995.

MARTINS, Eliane M. Octaviano. A sistemática de solução de controvérsias no âmbito da OMC. Disponível em: <http://www.planalto.gov.br/ccivil_03/revista/ Rev_40/artigos/ art_Eliane.htm>. Acesso em: 14 out. 2014.

MAZZUOLI, Valério de Oliveira; SILVA, Roberto Luiz (Orgs.). O Brasile os Acordos Econômicos Internacionais: perspectivas jurídicas e econômicas à luz dos acordos com o FMI. São Paulo: Revista dos Tribunais, 2003.

MELlO, Celso de Albuquerque. Curso de direito internacional público. Rio de Janeiro: Renovar, 2004. v. 2.

MESQUITA, Paulo Estivallet de. A Organização Mundial do Comércio. Brasília: FUNAG, 2013. 
NARLIKAR, Amrita. The World Trade Organization: a very short introduction. New York: Oxford University Press, 2005.

NARLIKAR, Amrita; DAUNTON, Martin; STERN, Robert M. The Oxford Handbook on the World Trade Organization. New York: Oxford University Press, 2012.

RODRIGUES, Tatiana S. Fukuda; PAULA, Nilson M. de. A agricultura nas negociacõoes multilaterais da Rodada Doba e suas implicações para o Brasil. Disponível em: <http:// ojs.c3sl.ufpr.br/ojs/index.php/economia/article/ viewFile/12297/8514>. Acesso em: 14 out. 2014.

SALDANHA, Eduardo. Desenvolvimento e tratamento especial e diferenciado na OMC: uma abordagem sob a perspectiva da doutrina do stare decisis - Parte II. Disponível em: <http://www2.pucpr.br/reol/index. $\mathrm{php} /$ direitoeconomico?dd $99=\mathrm{pdf \& dd} 1=7547>$. Acesso em: 16 out. 2014.

SEITENFUS, Ricardo Antônio Silva. Manual das organizaçôes internacionais. 3. ed. Porto Alegre: Livraria do Advogado, 2003.
WORLD TRADE ORGANIZATION. Brasil and the WTO. Disponível em: <http://www.wto.org/english/ thewto_e/countries_e/brazil_e.htm\#disputes $>$. Acesso em: 16 out. 2014.

WORLD TRADE ORGANIZATION. Dispute settlement: Dispute ds222. Disponível em: <http://www. wto.org/english/tratop_e/dispu_e/cases_e/ds222_e. htm>. Acesso em: 19 out. 2014.

WORLD TRADE ORGANIZATION. Disputing cases envolving Brazil. Disponível em: <http://www. wto.org/english/thewto_e/countries_e/brazil_e. htm\#disputes>. Acesso em: 17 out. 2014.

YOSHIURA, Jackson Apolinário. Os países em desenvolvimento no sistema de solução de controvérsias da OMC. Boletim de Ciências Económicas, Coimbra, v. 53, 2010, p. 95-181. Disponível em: <https://digitalisdsp.uc.pt/bitstream/10316.2/24714/1/BoletimLIII_ Artigo4.pdf>. Acesso em: 18 out. 2014. 
Para publicar na Revista de Direito Internacional, acesse o endereço eletrônico www.rdi.uniceub.br ou www.brazilianjournal.org.

Observe as normas de publicação, para facilitar e agilizar o trabalho de edição. 